\title{
WHERE TO FILE YOUR PATENT CASE
}

Mark A. Lemley*

Abstract

Forum shopping is a feature of modern patent law. Both plaintiffs and defendants do it. But they have traditionally done it on the basis of anecdote and personal experience, not on the basis of actual data. In this paper, I evaluate the records of the thirty-three most active patent district courts, considering plaintiff win rate, the likelihood of getting to trial, and the speed of the forum. The result is a surprising answer to the question "Where should I file my patent case?"

\section{LIST OF TABLES}

1. Table 1. District Court Outcomes 2000-2010 ..........................................4

2. Table 2. Number of Patent Cases Litigated in Districts with 25 or More

Outcomes ........................................................................................5

3. Table 3. Patentee Win Rate in Districts with 25 or More Outcomes.......7

4. Table 4. Percentage of Patent Cases that Result in Trial in Districts with 25 or More Outcomes ......................................................11

5. Table 5. Districts with 25 or More Outcomes, Sorted by Time to Resolution ...............................................................................14

6. Table 6. Districts with 25 or More Outcomes, Sorted by Time to Trial 16

7. Table 7. Aggregate Ranking of Districts................................................18

8. Table 8. Outcome-Emphasis Ranking of Districts with 25 or More Outcomes .........................................................................21

9. Table 9. Trial-Emphasis Ranking of Districts with 25 or More Outcomes .

* (C) 2010 Mark A. Lemley. William H. Neukom Professor, Stanford Law School; partner, Durie Tangri LLP, San Francisco, California. This paper could not have been written without the Stanford IP Litigation Clearinghouse (IPLC), available at lexmachina.com, and I thank both the tireless workers there and the many companies that have sponsored the IPLC. Thanks also to Daralyn Durie, Rose Hagan, David McCombs, Clem Roberts, and Bill Rooklidge for comments on a prior draft. 
10. Table 10. Speed-Emphasis Ranking of Districts with 25 or More

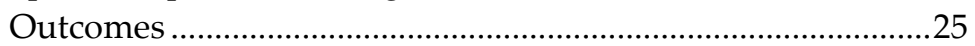

11. Table 11. Appendix A: Patent Litigation Outcomes by Court ................28 
Forum shopping is alive and well in patent law. The patent venue statute allows plaintiffs to file suit anywhere in the country where the defendant's product is sold or used. ${ }^{1}$ Despite the existence of a unified court of appeals that hears virtually all patent cases, ${ }^{2}$ patent plaintiffs - and those who might become patent defendants - spend a great deal of time and effort worrying about where to file their case. ${ }^{3}$ Meanwhile, accused infringers play much the same game, looking for defense-favorable jurisdictions in which to file declaratory judgment actions. ${ }^{4}$ The result in many cases is a race to the courthouse. The Federal Circuit has acted recently to rein in the worst abuses, ${ }^{5}$ but forum shopping shows no signs of disappearing.

When selecting a forum, patent owners generally look for a few specific characteristics. First, of course, they want to win. Therefore, the fact that a court is considered pro-patentee is, not surprisingly, a strong reason to file suit there. Second, at a minimum, patent plaintiffs want to get to trial. They know that most summary judgment rulings favor defendants in patent cases, but that juries

128 U.S.C. § 1400(b) (2006) ("Any civil action . . . may be brought . . . where the defendant has committed acts of infringement and has a regular and established place of business.").

$2 \quad$ See 28 U.S.C. $\S \S 1295(a)(1), 1338(a)$ (2006).

3 Among the academic discussions of patent forum shopping and costs of patent litigation, see Samson Vermont, The Economics of Patent Litigation, in FROM IDEAS TO ASSETS: INVESTING WISELY IN INTELLECTUAL PROPERTY 327, 327-71 (Bruce Berman ed., John Wiley \& Sons, Inc. 2002); Mark Chandler, The Patent System's Relationship to Digital Entrepreneurship, 112 W. VA. L. REV. 199, 203; Kimberly A. Moore, Forum Shopping in Patent Cases: Does Geographic Choice Affect Innovation?, 79 N.C. L. REV. 889, 928 (2001). Carter Phillips calls forum shopping a "serious problem" in patent litigation. Carter G. Phillips, Lewis F. Powell, Jr. Distinguished Lecture Series, 66 WASH. \& LEE L. REV. 1467, 1472 (2009).

4 It can be a substantial advantage to sue first as an accused infringer. Kimberly Moore's study found that patentees won $68 \%$ of jury trials when they were the plaintiff but only $38 \%$ when they were the defendant in a declaratory judgment action. Kimberly A. Moore, Judges, Juries, and Patent Cases-An Empirical Peek Inside the Black Box, 99 MicH. L. Rev. 365, 368 (2000).

$5 \quad$ See In re Genentech, Inc., 566 F.3d 1338, 1348, 91 U.S.P.Q.2d (BNA) 1027, 1035 (Fed. Cir. 2009); In re Hoffmann-La Roche Inc., 587 F.3d 1333, 1336-37, 92 U.S.P.Q.2d (BNA) 1861, 1862-63 (Fed. Cir. 2009); In re TS Tech USA Corp., 551 F.3d 1315, 1320-21, 89 U.S.P.Q.2d (BNA) 1567, 1569-70 (Fed. Cir. 2008). 
tend to be far more pro-patentee. ${ }^{6}$ As a result, a jurisdiction that grants many summary judgment motions is likely to be a defense jurisdiction, while a court that allows many matters to go to trial is likely to end up favoring the patentee. Third, patent plaintiffs generally want speed. Because a patent usually expires after twenty years, ${ }^{7}$ it is a wasting asset; every year waiting to enforce the right in court is a year that a patentee doesn't have exclusivity in the market. For plaintiffs only interested in damages, delay is somewhat less of a problem, because the damages will ultimately compensate for the defendant's use during the court proceeding and the courts routinely award prejudgment interest. Nonetheless, time spent waiting for a court resolution is time that cannot be spent using the proceeds of the first suit to sue others. Further, while plaintiffs wait for a court resolution, defendants can design around the patentee's invention, and delay may also bring market changes that render the patented invention less valuable. ${ }^{8}$

Defendants, in turn, generally want the opposite of what plaintiffs want. A defendant's ideal jurisdiction is one that regularly rules for defendants, is unlikely to send cases to jury trial, and takes a long time to do both. The incentives aren't always perfectly misaligned-for example, a small defendant with limited resources may be happy in a jurisdiction that resolves cases quickly-but in general what plaintiffs want and what defendants want are opposites.

Until recently, there was no good source of information about the characteristics of the different district courts. Instead, lawyers tended to rely on a combination of anecdote and their own experiences with a jurisdiction when

6 See, e.g., John R. Allison \& Mark A. Lemley, Empirical Evidence on the Validity of Litigated Patents, 26 AIPLA Q.J. 185, 212-13 (1998) (finding that patentees win $67 \%$ of jury verdicts on validity but only $28 \%$ of pretrial motions).

$7 \quad$ See 35 U.S.C. $§ 154(\mathrm{a})(2)$ (2006) (providing patents with a twenty year term of exclusivity); 35 U.S.C. $\S 156(c)$ (2006) (allowing extension of term of exclusivity equal to the regulatory review period to which the product is subject, in certain circumstances); 35 U.S.C. § 154(b) (providing a number of extensions of patent term).

8 At the same time, delay can increase the cost of litigation and, especially if the plaintiff's lawyer is on contingency, that cost may be borne by the defendant. See, e.g., Steven J. Elleman, Problems in Patent Litigation: Mandatory Mediation May Provide Settlements and Solutions, 12 Ohio St. J. on Disp. Resol. 759, 762-63 (1997). As a result, some plaintiffs do not particularly care about speed. 
deciding where to file a patent case. This led to a herd mentality, in which patent plaintiffs flock en masse to a particular jurisdiction perceived as favorable-the Eastern District of Virginia a decade ago; ${ }^{9}$ the Eastern District of Texas in the last several years. ${ }^{10}$ Speculation abounds about the next hot forum for patent litigation-the Western District of Wisconsin? The Southern District of Florida? In each instance, assessing the likelihood of winning, or even the likelihood of trial in a patent case, was difficult, so plaintiffs focused primarily on what they could observe: how fast a court's docket moves.

The development of the Stanford Intellectual Property Litigation Clearinghouse ("IPLC") allows for a more systematic approach. The IPLC"11 is a comprehensive set of data on every patent lawsuit filed since 2000-more than 25,000 suits in all. In this Article, I survey the outcome data of all 21,667 cases in the IPLC database that were resolved at the district court level by March 17, 2010. The results are presented in Table 1:

Table 1: District Court Outcomes 2000-2010

\begin{tabular}{|c|c|c|c|c|c|c|c|}
\hline 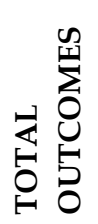 & 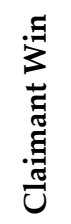 & 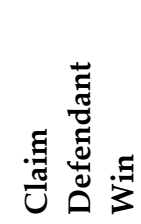 & 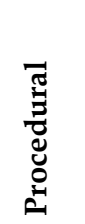 & 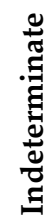 & 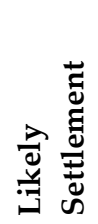 & 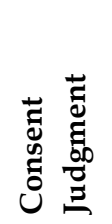 & 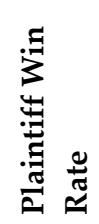 \\
\hline 21,667 & 989 & 2,054 & 2,223 & 37 & 14,542 & 1,822 & $32.5 \%$ \\
\hline
\end{tabular}

Not surprisingly, most patent cases $(75.5 \%)$ settle. When cases do go to judgment, and almost $15 \%$ do, patentees win 989 out of 3,043 , or $32.5 \% .^{12}$

9 See George F. Pappas \& Robert G. Sterne, Patent Litigation in the Eastern District of Virginia, 35 IDEA 361, 363 (1995).

10 See Yan Leychkis, Of Fire Ants and Claim Construction: An Empirical Study of the Meteoric Rise of the Eastern District of Texas as a Preeminent Forum for Patent Litigation, 9 YALE J.L. \& TECH. 193, 204 (2007).

11 Available without charge at http://www.lexmachina.org for academic, government, and non-profit users, and by subscription for commercial users at http://www.lexmachina.com.

12 This does not include consent judgments; adding those would increase the number substantially. But consent judgments are really settlements, not rulings on the merits. 
The overall percentage (32.5\%) of patentees who win, however, conceals substantial variation in outcome by district. There are jurisdictions where the patentee win rate is $100 \%$ (the Middle District of Georgia, for example), and jurisdictions where it is $0 \%$ (the District of Wyoming). But these are outliers in districts where small numbers of cases are filed; one can't predict very much about the District of Wyoming by knowing that the only patent case ever resolved there on the merits in the last decade went for the defense. As a result, I limit my analysis to districts that resolved twenty-five or more cases on the merits in the last decade. ${ }^{13}$ There are thirty-three such districts. In Table 2, I list these districts in decreasing order by the number of patent cases litigated there in the last decade.

Table 2: Number of Patent Cases Litigated in Districts with 25 or More Outcomes

\begin{tabular}{|c|c|c|c|c|c|c|c|}
\hline 菢 & 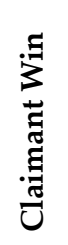 & 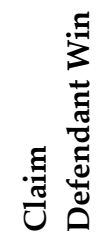 & 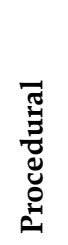 & 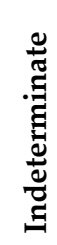 & 롤 & 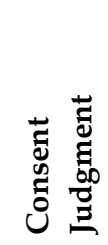 & 崖 \\
\hline $\begin{array}{l}\text { Central District } \\
\text { of California }\end{array}$ & 125 & 219 & 193 & 11 & 1401 & 340 & 2289 \\
\hline $\begin{array}{l}\text { Northern } \\
\text { District of } \\
\text { California }\end{array}$ & 56 & 159 & 131 & 0 & 1007 & 71 & 1424 \\
\hline $\begin{array}{l}\text { Northern } \\
\text { District of } \\
\text { Illinois }\end{array}$ & 47 & 97 & 119 & 3 & 874 & 93 & 1233 \\
\hline $\begin{array}{l}\text { Eastern District } \\
\text { of Texas }\end{array}$ & 52 & 77 & 150 & 0 & 703 & 42 & 1024 \\
\hline $\begin{array}{l}\text { Southern } \\
\text { District of New } \\
\text { York }\end{array}$ & 51 & 87 & 87 & 1 & 676 & 116 & 1018 \\
\hline $\begin{array}{l}\text { District of } \\
\text { Delaware }\end{array}$ & 62 & 75 & 137 & 0 & 682 & 61 & 1017 \\
\hline $\begin{array}{l}\text { District of New } \\
\text { Jersey }\end{array}$ & 29 & 109 & 201 & 0 & 588 & 60 & 987 \\
\hline $\begin{array}{l}\text { District of } \\
\text { Minnesota }\end{array}$ & 25 & 54 & 28 & 0 & 450 & 43 & 600 \\
\hline $\begin{array}{l}\text { District of } \\
\text { Massachusetts }\end{array}$ & 43 & 69 & 41 & 1 & 392 & 38 & 584 \\
\hline
\end{tabular}

13 A full list of cases for every district is attached as Appendix A. 


\begin{tabular}{|c|c|c|c|c|c|c|c|}
\hline $\begin{array}{l}\text { Southern } \\
\text { District of } \\
\text { California } \\
\end{array}$ & 21 & 56 & 24 & 1 & 380 & 37 & 519 \\
\hline $\begin{array}{l}\text { Eastern District } \\
\text { of Michigan }\end{array}$ & 18 & 54 & 34 & 0 & 378 & 30 & 514 \\
\hline $\begin{array}{l}\text { Southern } \\
\text { District of } \\
\text { Florida }\end{array}$ & 25 & 65 & 71 & 1 & 282 & 34 & 478 \\
\hline $\begin{array}{l}\text { Eastern District } \\
\text { of Pennsylvania }\end{array}$ & 15 & 40 & 42 & 3 & 342 & 33 & 475 \\
\hline $\begin{array}{l}\text { Northern } \\
\text { District of } \\
\text { Georgia }\end{array}$ & 7 & 54 & 69 & 1 & 265 & 61 & 457 \\
\hline $\begin{array}{l}\text { Middle District } \\
\text { of Florida }\end{array}$ & 25 & 29 & 49 & 2 & 277 & 47 & 429 \\
\hline $\begin{array}{l}\text { Northern } \\
\text { District of } \\
\text { Texas }\end{array}$ & 27 & 22 & 55 & 0 & 283 & 18 & 405 \\
\hline $\begin{array}{l}\text { Western } \\
\text { District of } \\
\text { Washington }\end{array}$ & 11 & 44 & 56 & 0 & 248 & 33 & 392 \\
\hline $\begin{array}{l}\text { Eastern District } \\
\text { of Virginia }\end{array}$ & 14 & 32 & 69 & 1 & 229 & 28 & 373 \\
\hline $\begin{array}{l}\text { District of } \\
\text { Colorado }\end{array}$ & 9 & 27 & 28 & 0 & 285 & 17 & 366 \\
\hline District of Utah & 15 & 39 & 34 & 2 & 247 & 20 & 357 \\
\hline $\begin{array}{l}\text { Southern } \\
\text { District of } \\
\text { Texas } \\
\end{array}$ & 17 & 41 & 51 & 2 & 214 & 18 & 343 \\
\hline $\begin{array}{l}\text { Northern } \\
\text { District of Ohio }\end{array}$ & 13 & 33 & 14 & 0 & 268 & 15 & 343 \\
\hline $\begin{array}{l}\text { Eastern District } \\
\text { of New York }\end{array}$ & 6 & 28 & 29 & 0 & 245 & 34 & 342 \\
\hline $\begin{array}{l}\text { Eastern District } \\
\text { of Missouri }\end{array}$ & 16 & 24 & 26 & 0 & 170 & 55 & 291 \\
\hline $\begin{array}{l}\text { District of } \\
\text { Arizona }\end{array}$ & 10 & 23 & 28 & 0 & 193 & 17 & 271 \\
\hline $\begin{array}{l}\text { Western } \\
\text { District of } \\
\text { Wisconsin } \\
\end{array}$ & 12 & 38 & 31 & 2 & 155 & 18 & 256 \\
\hline $\begin{array}{l}\text { District of } \\
\text { Oregon }\end{array}$ & 19 & 23 & 8 & 0 & 160 & 41 & 251 \\
\hline
\end{tabular}




\begin{tabular}{|l|l|l|l|l|l|l|l|}
\hline $\begin{array}{l}\text { District of } \\
\text { Maryland }\end{array}$ & 7 & 21 & 40 & 0 & 161 & 13 & 242 \\
\hline $\begin{array}{l}\text { Eastern District } \\
\text { of Wisconsin }\end{array}$ & 7 & 34 & 21 & 0 & 162 & 17 & 241 \\
\hline $\begin{array}{l}\text { Southern } \\
\text { District of Ohio }\end{array}$ & 8 & 22 & 23 & 0 & 149 & 16 & 218 \\
\hline $\begin{array}{l}\text { Western } \\
\text { District of } \\
\text { Texas }\end{array}$ & 9 & 18 & 17 & 0 & 151 & 5 & 200 \\
\hline $\begin{array}{l}\text { District of } \\
\text { Nevada }\end{array}$ & 24 & 28 & 15 & 0 & 117 & 14 & 198 \\
\hline $\begin{array}{l}\text { District of } \\
\text { Columbia }\end{array}$ & 9 & 25 & 19 & 0 & 59 & 3 & 115 \\
\hline
\end{tabular}

The districts with the most patent cases largely track population and technology centers-Northern California, Los Angeles, Chicago, New York and New Jersey - with two exceptions: the District of Delaware, which is the state of incorporation of many litigants, and the Eastern District of Texas, which has little connection to innovation, except its choice as a destination for patent plaintiffs.

Even among these districts, the patentee win rate varies substantially. Table 3 sorts the top thirty-three districts by patentee win rate.

Table 3: Patentee Win Rate in Districts with 25 or More Outcomes

\begin{tabular}{|c|c|c|c|c|c|c|c|c|}
\hline 䓪 & 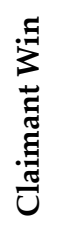 & 疍 & 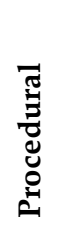 & 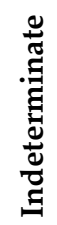 & 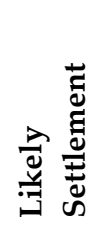 & 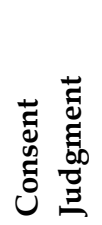 & 离 & 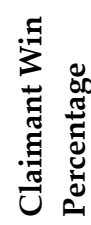 \\
\hline $\begin{array}{l}\text { Northern } \\
\text { District of } \\
\text { Texas }\end{array}$ & 27 & 22 & 55 & 0 & 283 & 18 & 405 & $55.1 \%$ \\
\hline $\begin{array}{l}\text { Middle } \\
\text { District of } \\
\text { Florida }\end{array}$ & 25 & 29 & 49 & 2 & 277 & 47 & 429 & $46.3 \%$ \\
\hline $\begin{array}{l}\text { District of } \\
\text { Nevada }\end{array}$ & 24 & 28 & 15 & 0 & 117 & 14 & 198 & $46.2 \%$ \\
\hline $\begin{array}{l}\text { District of } \\
\text { Delaware }\end{array}$ & 62 & 75 & 137 & 0 & 682 & 61 & 1017 & $45.3 \%$ \\
\hline $\begin{array}{l}\text { District of } \\
\text { Oregon }\end{array}$ & 19 & 23 & 8 & 0 & 160 & 41 & 251 & $45.2 \%$ \\
\hline
\end{tabular}




\begin{tabular}{|c|c|c|c|c|c|c|c|c|}
\hline $\begin{array}{l}\text { Eastern } \\
\text { District of } \\
\text { Texas }\end{array}$ & 52 & 77 & 150 & 0 & 703 & 42 & 1024 & $40.3 \%$ \\
\hline $\begin{array}{l}\text { Eastern } \\
\text { District of } \\
\text { Missouri } \\
\end{array}$ & 16 & 24 & 26 & 0 & 170 & 55 & 291 & $40.0 \%$ \\
\hline $\begin{array}{l}\text { District of } \\
\text { Massachusetts }\end{array}$ & 43 & 69 & 41 & 1 & 392 & 38 & 584 & $38.4 \%$ \\
\hline $\begin{array}{l}\text { Southern } \\
\text { District of } \\
\text { New York }\end{array}$ & 51 & 87 & 87 & 1 & 676 & 116 & 1018 & $37.0 \%$ \\
\hline $\begin{array}{l}\text { Central } \\
\text { District of } \\
\text { California }\end{array}$ & 125 & 219 & 193 & 11 & 1401 & 340 & 2289 & $36.3 \%$ \\
\hline $\begin{array}{l}\text { Western } \\
\text { District of } \\
\text { Texas }\end{array}$ & 9 & 18 & 17 & 0 & 151 & 5 & 200 & $33.3 \%$ \\
\hline $\begin{array}{l}\text { Northern } \\
\text { District of } \\
\text { Illinois }\end{array}$ & 47 & 97 & 119 & 3 & 874 & 93 & 1233 & $32.6 \%$ \\
\hline $\begin{array}{l}\text { District of } \\
\text { Minnesota }\end{array}$ & 25 & 54 & 28 & 0 & 450 & 43 & 600 & $31.6 \%$ \\
\hline $\begin{array}{l}\text { Eastern } \\
\text { District of } \\
\text { Virginia } \\
\end{array}$ & 14 & 32 & 69 & 1 & 229 & 28 & 373 & $30.4 \%$ \\
\hline $\begin{array}{l}\text { District of } \\
\text { Arizona }\end{array}$ & 10 & 23 & 28 & 0 & 193 & 17 & 271 & $30.3 \%$ \\
\hline $\begin{array}{l}\text { Southern } \\
\text { District of } \\
\text { Texas } \\
\end{array}$ & 17 & 41 & 51 & 2 & 214 & 18 & 343 & $29.3 \%$ \\
\hline $\begin{array}{l}\text { Northern } \\
\text { District of } \\
\text { Ohio } \\
\end{array}$ & 13 & 33 & 14 & 0 & 268 & 15 & 343 & $28.3 \%$ \\
\hline $\begin{array}{l}\text { Southern } \\
\text { District of } \\
\text { Florida } \\
\end{array}$ & 25 & 65 & 71 & 1 & 282 & 34 & 478 & $27.8 \%$ \\
\hline $\begin{array}{l}\text { District of } \\
\text { Utah }\end{array}$ & 15 & 39 & 34 & 2 & 247 & 20 & 357 & $27.8 \%$ \\
\hline $\begin{array}{l}\text { Southern } \\
\text { District of } \\
\text { California } \\
\end{array}$ & 21 & 56 & 24 & 1 & 380 & 37 & 519 & $27.3 \%$ \\
\hline $\begin{array}{l}\text { Eastern } \\
\text { District of } \\
\text { Pennsylvania }\end{array}$ & 15 & 40 & 42 & 3 & 342 & 33 & 475 & $27.3 \%$ \\
\hline
\end{tabular}




\begin{tabular}{|c|c|c|c|c|c|c|c|c|}
\hline $\begin{array}{l}\text { Southern } \\
\text { District of } \\
\text { Ohio }\end{array}$ & 8 & 22 & 23 & 0 & 149 & 16 & 218 & $26.7 \%$ \\
\hline $\begin{array}{l}\text { District of } \\
\text { Columbia }\end{array}$ & 9 & 25 & 19 & 0 & 59 & 3 & 115 & $26.5 \%$ \\
\hline $\begin{array}{l}\text { Northern } \\
\text { District of } \\
\text { California } \\
\end{array}$ & 56 & 159 & 131 & 0 & 1007 & 71 & 1424 & $26.0 \%$ \\
\hline $\begin{array}{l}\text { Eastern } \\
\text { District of } \\
\text { Michigan }\end{array}$ & 18 & 54 & 34 & 0 & 378 & 30 & 514 & $25.0 \%$ \\
\hline $\begin{array}{l}\text { District of } \\
\text { Colorado }\end{array}$ & 9 & 27 & 28 & 0 & 285 & 17 & 366 & $25.0 \%$ \\
\hline $\begin{array}{l}\text { District of } \\
\text { Maryland }\end{array}$ & 7 & 21 & 40 & 0 & 161 & 13 & 242 & $25.0 \%$ \\
\hline $\begin{array}{l}\text { Western } \\
\text { District of } \\
\text { Wisconsin }\end{array}$ & 12 & 38 & 31 & 2 & 155 & 18 & 256 & $24.0 \%$ \\
\hline $\begin{array}{l}\text { District of } \\
\text { New Jersey }\end{array}$ & 29 & 109 & 201 & 0 & 588 & 60 & 987 & $21.0 \%$ \\
\hline $\begin{array}{l}\text { Western } \\
\text { District of } \\
\text { Washington }\end{array}$ & 11 & 44 & 56 & 0 & 248 & 33 & 392 & $20.0 \%$ \\
\hline $\begin{array}{l}\text { Eastern } \\
\text { District of } \\
\text { New York } \\
\end{array}$ & 6 & 28 & 29 & 0 & 245 & 34 & 342 & $17.6 \%$ \\
\hline $\begin{array}{l}\text { Eastern } \\
\text { District of } \\
\text { Wisconsin } \\
\end{array}$ & 7 & 34 & 21 & 0 & 162 & 17 & 241 & $17.1 \%$ \\
\hline $\begin{array}{l}\text { Northern } \\
\text { District of } \\
\text { Georgia }\end{array}$ & 7 & 54 & 69 & 1 & 265 & 61 & 457 & $11.5 \%$ \\
\hline \multirow[t]{2}{*}{$\begin{array}{l}\text { TOTAL } \\
\text { OUTCOMES }\end{array}$} & 芯 & 当 & 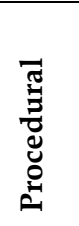 & 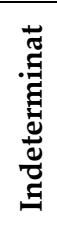 & 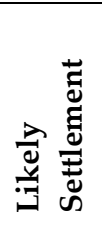 & 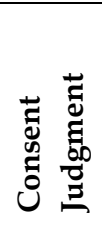 & 范 & 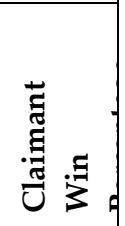 \\
\hline & 989 & 2054 & 2223 & 37 & 14542 & 1822 & 21667 & $32.5 \%$ \\
\hline
\end{tabular}

The variation in win rates ranges from a high of $55 \%$ in the Northern District of Texas to a low of $11.5 \%$ in the Northern District of Georgia. Statistically, then, it seems that the jurisdiction in which a case is litigated has a 
significant impact on its outcome. ${ }^{14}$ Even limiting the analysis to the largest districts-those with more than 100 judgments on the merits - the variation is substantial, ranging from a high of $45.3 \%$ in the District of Delaware to a low of $21 \%$ in the District of New Jersey. Notably, the Eastern District of Texas, while having a higher than average plaintiff win rate, is not in the top five districts. Moreover, the districts that are in the top five (the Northern District of Texas, the Middle District of Florida, the District of Nevada, the District of Delaware, and the District of Oregon) are not normally thought of as patent plaintiffs' jurisdictions of choice. Indeed, accused infringers often choose the District of Delaware, filing declaratory judgment actions there. Conversely, patent plaintiffs often file suit in districts, like the District of New Jersey, that have a surprisingly low win rate. In short, if patentees or accused infringers are to pick a forum only by win rate, both sides should probably be picking different districts than they do.

It is important to note, however, that your mileage may vary. The win rate in any district will be a function of the merits of the cases filed there. For example, one experienced litigator suggested to me that patentees fare so well in the District of Nevada and the Middle District of Florida because those jurisdictions are home to many trade shows, and cases brought against a new product demonstrated at a trade show may be stronger than the average patent case. So the fact that patentees have won in a district in the past doesn't mean you will win if you file there. Indeed, the fact that plaintiffs gravitate to a particular jurisdiction because it is viewed as plaintiff-friendly may reduce the ultimate win rate if those plaintiffs assert patents of lower overall quality than the cases filed before the influx.

Of course, win rate is not all that matters. Most cases don't go to judgment, after all. And if the patentee is interested in trial-which is where the patentee win rate is the highest, and the largest judgments are possible-things look rather different. Table 4 ranks the top thirty-three districts by the percentage of patent cases that make it to trial.

14 To be clear, this is not a causal claim: it may be the nature of the cases, the lawyers, or something else that explains part or all of this difference. 
Table 4: Percentage of Patent Cases that Result in Trial in Districts with 25 or More Outcomes

\begin{tabular}{|c|c|c|c|c|c|c|c|}
\hline 泀 & 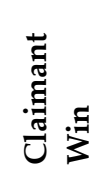 & 丞 売 & 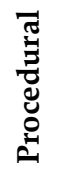 & 趈 & 节 & 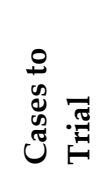 & 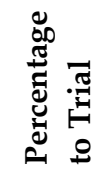 \\
\hline $\begin{array}{l}\text { District of } \\
\text { Delaware }\end{array}$ & 62 & 75 & & 1017 & $45.3 \%$ & 120 & $11.8 \%$ \\
\hline $\begin{array}{l}\text { Eastern } \\
\text { District of } \\
\text { Texas }\end{array}$ & 52 & 77 & & 1024 & $40.3 \%$ & 82 & $8.0 \%$ \\
\hline $\begin{array}{l}\text { Western } \\
\text { District of } \\
\text { Wisconsin }\end{array}$ & 12 & 38 & & 256 & $24.0 \%$ & 19 & $7.4 \%$ \\
\hline $\begin{array}{l}\text { Eastern } \\
\text { District of } \\
\text { Virginia }\end{array}$ & 14 & 32 & & 373 & $30.4 \%$ & 24 & $6.4 \%$ \\
\hline $\begin{array}{l}\text { District of } \\
\text { Massachusetts }\end{array}$ & 43 & 69 & & 584 & $38.4 \%$ & 36 & $6.2 \%$ \\
\hline $\begin{array}{l}\text { Southern } \\
\text { District of } \\
\text { Florida }\end{array}$ & 25 & 65 & & 478 & $27.8 \%$ & 21 & $4.4 \%$ \\
\hline $\begin{array}{l}\text { Eastern } \\
\text { District of } \\
\text { Missouri } \\
\end{array}$ & 16 & 24 & & 291 & $40.0 \%$ & 12 & $4.1 \%$ \\
\hline $\begin{array}{l}\text { Western } \\
\text { District of } \\
\text { Texas }\end{array}$ & 9 & 18 & & 200 & $33.3 \%$ & 8 & $4.0 \%$ \\
\hline $\begin{array}{l}\text { Middle } \\
\text { District of } \\
\text { Florida } \\
\end{array}$ & 25 & 29 & & 429 & $46.3 \%$ & 17 & $4.0 \%$ \\
\hline $\begin{array}{l}\text { Southern } \\
\text { District of } \\
\text { Texas }\end{array}$ & 17 & 41 & & 343 & $29.3 \%$ & 12 & $3.5 \%$ \\
\hline $\begin{array}{l}\text { District of } \\
\text { Oregon }\end{array}$ & 19 & 23 & & 251 & $45.2 \%$ & 8 & $3.2 \%$ \\
\hline $\begin{array}{l}\text { Northern } \\
\text { District of } \\
\text { California } \\
\end{array}$ & 56 & 159 & & 1424 & $26.0 \%$ & 44 & $3.1 \%$ \\
\hline $\begin{array}{l}\text { Southern } \\
\text { District of } \\
\text { California } \\
\end{array}$ & 21 & 56 & & 519 & $27.3 \%$ & 16 & $3.1 \%$ \\
\hline
\end{tabular}




\begin{tabular}{|c|c|c|c|c|c|c|}
\hline $\begin{array}{l}\text { District of } \\
\text { Arizona }\end{array}$ & 10 & 23 & 271 & $30.3 \%$ & 7 & $2.6 \%$ \\
\hline $\begin{array}{l}\text { District of } \\
\text { Nevada }\end{array}$ & 24 & 28 & 198 & $46.2 \%$ & 5 & $2.5 \%$ \\
\hline $\begin{array}{l}\text { District of } \\
\text { Maryland }\end{array}$ & 7 & 21 & 242 & $25.0 \%$ & 6 & $2.5 \%$ \\
\hline $\begin{array}{l}\text { Northern } \\
\text { District of } \\
\text { Texas }\end{array}$ & 27 & 22 & 405 & $55.1 \%$ & 10 & $2.5 \%$ \\
\hline $\begin{array}{l}\text { District of } \\
\text { Minnesota }\end{array}$ & 25 & 54 & 600 & $31.6 \%$ & 14 & $2.3 \%$ \\
\hline $\begin{array}{l}\text { District of } \\
\text { Colorado }\end{array}$ & 9 & 27 & 366 & $25.0 \%$ & 8 & $2.2 \%$ \\
\hline $\begin{array}{l}\text { Eastern } \\
\text { District of } \\
\text { Michigan } \\
\end{array}$ & 18 & 54 & 514 & $25.0 \%$ & 11 & $2.1 \%$ \\
\hline $\begin{array}{l}\text { District of } \\
\text { New Jersey }\end{array}$ & 29 & 109 & 987 & $21.0 \%$ & 21 & $2.1 \%$ \\
\hline $\begin{array}{l}\text { Northern } \\
\text { District of } \\
\text { Georgia }\end{array}$ & 7 & 54 & 457 & $11.5 \%$ & 8 & $1.8 \%$ \\
\hline $\begin{array}{l}\text { Northern } \\
\text { District of } \\
\text { Illinois } \\
\end{array}$ & 47 & 97 & 1233 & $32.6 \%$ & 20 & $1.6 \%$ \\
\hline $\begin{array}{l}\text { Southern } \\
\text { District of } \\
\text { New York } \\
\end{array}$ & 51 & 87 & 1018 & $37.0 \%$ & 16 & $1.6 \%$ \\
\hline $\begin{array}{l}\text { Central } \\
\text { District of } \\
\text { California } \\
\end{array}$ & 125 & 219 & 2289 & $36.3 \%$ & 35 & $1.5 \%$ \\
\hline $\begin{array}{l}\text { Eastern } \\
\text { District of } \\
\text { Pennsylvania } \\
\end{array}$ & 15 & 40 & 475 & $27.3 \%$ & 7 & $1.5 \%$ \\
\hline $\begin{array}{l}\text { Northern } \\
\text { District of } \\
\text { Ohio } \\
\end{array}$ & 13 & 33 & 343 & $28.3 \%$ & 4 & $1.2 \%$ \\
\hline $\begin{array}{l}\text { Eastern } \\
\text { District of } \\
\text { New York } \\
\end{array}$ & 6 & 28 & 342 & $17.6 \%$ & 3 & $0.9 \%$ \\
\hline $\begin{array}{l}\text { Eastern } \\
\text { District of } \\
\text { Wisconsin } \\
\end{array}$ & 7 & 34 & 241 & $17.1 \%$ & 2 & $0.8 \%$ \\
\hline
\end{tabular}




\begin{tabular}{|c|c|c|c|c|c|c|c|}
\hline $\begin{array}{l}\text { Western } \\
\text { District of } \\
\text { Washington }\end{array}$ & 11 & 44 & & 392 & $20.0 \%$ & 3 & $0.8 \%$ \\
\hline $\begin{array}{l}\text { District of } \\
\text { Utah }\end{array}$ & 15 & 39 & & 357 & $27.8 \%$ & 2 & $0.6 \%$ \\
\hline $\begin{array}{l}\text { Southern } \\
\text { District of } \\
\text { Ohio }\end{array}$ & 8 & 22 & & 218 & $26.7 \%$ & 1 & $0.5 \%$ \\
\hline $\begin{array}{l}\text { District of } \\
\text { Columbia }\end{array}$ & 9 & 25 & & 115 & $26.5 \%$ & 0 & $0.0 \%$ \\
\hline \multirow[t]{2}{*}{$\begin{array}{l}\text { TOTAL } \\
\text { OUTCOMES }\end{array}$} & 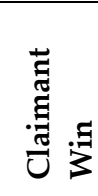 & : & 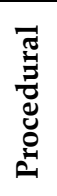 & 岕 & 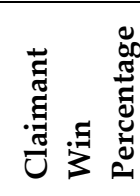 & 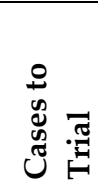 & 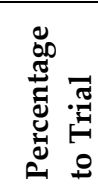 \\
\hline & 989 & 2054 & & 21667 & $32.5 \%$ & 602 & $2.8 \%$ \\
\hline
\end{tabular}

These numbers seem more reflective of the conventional wisdom among patent plaintiffs. While on average only $2.8 \%$ of patent cases go to trial, a far higher percentage make it to trial in the District of Delaware, the Eastern District of Texas, the Western District of Wisconsin, and the Eastern District of Virginia. With the exception of Delaware, all these are traditional patent plaintiff districts of choice. By contrast, six districts send less than $1 \%$ of their cases to trial. One might reasonably expect accused infringers to target those districts, though as mentioned above, many are-apparently foolishly-sending their cases to Delaware instead.

Finally, plaintiffs are frequently interested in speed. A speedy trial can hold down costs and get a plaintiff quick relief. A speedy settlement can have the same effect. Both can allow a patentee to build a war chest to sue other defendants, and, in the case of trial, build the reputation of the patent. Defendants' incentives are less clear; defendants generally want to delay any day of reckoning, and may think they can wear down a plaintiff in a long case, but they too will probably pay more in legal fees in slow jurisdictions than in fast ones. Table 5 ranks the district courts by their time to ultimate disposition of the case. 
Table 5: Districts with 25 or More Outcomes, Sorted by Time to Resolution

\begin{tabular}{|c|c|c|c|c|c|}
\hline & 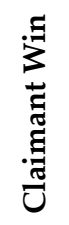 & 冚 & 芯 & 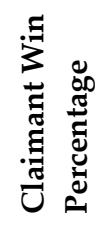 & 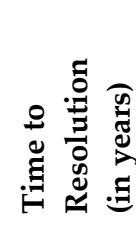 \\
\hline $\begin{array}{l}\text { Western District of } \\
\text { Wisconsin }\end{array}$ & 12 & 38 & 256 & $24.0 \%$ & 0.56 \\
\hline $\begin{array}{l}\text { Eastern District of } \\
\text { Virginia }\end{array}$ & 14 & 32 & 373 & $30.4 \%$ & 0.64 \\
\hline $\begin{array}{l}\text { Western District of } \\
\text { Washington }\end{array}$ & 11 & 44 & 392 & $20.0 \%$ & 0.80 \\
\hline $\begin{array}{l}\text { Southern District } \\
\text { of Florida }\end{array}$ & 25 & 65 & 478 & $27.8 \%$ & 0.83 \\
\hline $\begin{array}{l}\text { District of } \\
\text { Colorado }\end{array}$ & 9 & 27 & 366 & $25.0 \%$ & 0.88 \\
\hline $\begin{array}{l}\text { Middle District of } \\
\text { Florida }\end{array}$ & 25 & 29 & 429 & $46.3 \%$ & 0.89 \\
\hline $\begin{array}{l}\text { Central District of } \\
\text { California }\end{array}$ & 125 & 219 & 2289 & $36.3 \%$ & 0.89 \\
\hline $\begin{array}{l}\text { Northern District } \\
\text { of Ohio }\end{array}$ & 13 & 33 & 343 & $28.3 \%$ & 0.91 \\
\hline $\begin{array}{l}\text { Northern District } \\
\text { of Illinois }\end{array}$ & 47 & 97 & 1233 & $32.6 \%$ & 0.95 \\
\hline $\begin{array}{l}\text { Northern District } \\
\text { of Texas }\end{array}$ & 27 & 22 & 405 & $55.1 \%$ & 0.97 \\
\hline $\begin{array}{l}\text { Western District of } \\
\text { Texas }\end{array}$ & 9 & 18 & 200 & $33.3 \%$ & 0.98 \\
\hline $\begin{array}{l}\text { District of } \\
\text { Maryland }\end{array}$ & 7 & 21 & 242 & $25.0 \%$ & 1.00 \\
\hline $\begin{array}{l}\text { Northern District } \\
\text { of Georgia }\end{array}$ & 7 & 54 & 457 & $11.5 \%$ & 1.02 \\
\hline $\begin{array}{l}\text { Southern District } \\
\text { of California }\end{array}$ & 21 & 56 & 519 & $27.3 \%$ & 1.03 \\
\hline $\begin{array}{l}\text { District of } \\
\text { Delaware }\end{array}$ & 62 & 75 & 1017 & $45.3 \%$ & 1.05 \\
\hline $\begin{array}{l}\text { Southern District } \\
\text { of Texas }\end{array}$ & 17 & 41 & 343 & $29.3 \%$ & 1.06 \\
\hline District of Utah & 15 & 39 & 357 & $27.8 \%$ & 1.07 \\
\hline $\begin{array}{l}\text { Eastern District of } \\
\text { Missouri }\end{array}$ & 16 & 24 & 291 & $40.0 \%$ & 1.07 \\
\hline
\end{tabular}




\begin{tabular}{|l|l|l|l|l|l|}
\hline District of Nevada & 24 & 28 & 198 & $46.2 \%$ & 1.09 \\
\hline $\begin{array}{l}\text { Eastern District of } \\
\text { Michigan }\end{array}$ & 18 & 54 & 514 & $25.0 \%$ & 1.10 \\
\hline $\begin{array}{l}\text { Southern District } \\
\text { of New York }\end{array}$ & 51 & 87 & 1018 & $37.0 \%$ & 1.12 \\
\hline $\begin{array}{l}\text { Eastern District of } \\
\text { New York }\end{array}$ & 6 & 28 & 342 & $17.6 \%$ & 1.13 \\
\hline $\begin{array}{l}\text { District of } \\
\text { Columbia }\end{array}$ & 9 & 25 & 115 & $26.5 \%$ & 1.14 \\
\hline $\begin{array}{l}\text { District of New } \\
\text { Jersey }\end{array}$ & 29 & 109 & 987 & $21.0 \%$ & 1.14 \\
\hline District of Oregon & 19 & 23 & 251 & $45.2 \%$ & 1.14 \\
\hline $\begin{array}{l}\text { District of } \\
\text { Minnesota }\end{array}$ & 25 & 54 & 600 & $31.6 \%$ & 1.18 \\
\hline $\begin{array}{l}\text { Eastern District of } \\
\text { Wisconsin }\end{array}$ & 7 & 34 & 241 & $17.1 \%$ & 1.21 \\
\hline $\begin{array}{l}\text { Eastern District of } \\
\text { Texas }\end{array}$ & 52 & 77 & 1024 & $40.3 \%$ & 1.24 \\
\hline $\begin{array}{l}\text { Southern District } \\
\text { of Ohio }\end{array}$ & 8 & 22 & 218 & $26.7 \%$ & 1.28 \\
\hline $\begin{array}{l}\text { Northern District } \\
\text { of California }\end{array}$ & 56 & 159 & 1424 & $26.0 \%$ & 1.28 \\
\hline District of Arizona & 10 & 23 & 271 & $30.3 \%$ & 1.28 \\
\hline $\begin{array}{l}\text { District of } \\
\text { Massachusetts }\end{array}$ & 43 & 69 & 584 & $38.4 \%$ & 1.29 \\
\hline $\begin{array}{l}\text { Eastern District of } \\
\text { Pennsylvania }\end{array}$ & 15 & 40 & 475 & $27.3 \%$ & 1.32 \\
\hline
\end{tabular}

The differences here are not that dramatic. Most districts take approximately a year to resolve the average patent case. But there are some notable - and well-known - "rocket dockets." The Western District of Wisconsin and the Eastern District of Virginia resolve the average case in just over six months. The Western District of Washington and the Southern District of Florida are not far behind. Interestingly, the Eastern District of Texas is among the slowest jurisdictions, only slightly faster than the Northern District of California. This is likely a function of congestion resulting from its popularity as a patent forum; the sense in the bar in the early 2000s was that the Eastern District of 
Texas was a fast docket. ${ }^{15}$ Here too your mileage may vary; if everyone moves to a fast district, it can easily become a slow district as a result.

Related to time to resolution is time to trial. Table 6 ranks the districts by time to trial.

Table 6: Districts with 25 or More Outcomes, Sorted by Time to Trial

\begin{tabular}{|c|c|c|c|c|c|c|c|}
\hline 萨 & 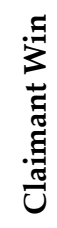 & 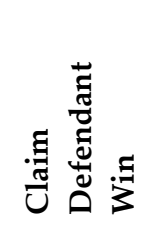 & 岕 & 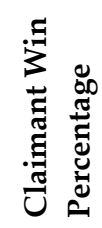 & 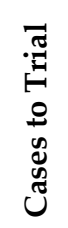 & 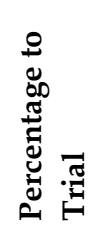 & 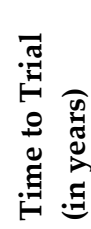 \\
\hline $\begin{array}{l}\text { Western } \\
\text { District of } \\
\text { Wisconsin }\end{array}$ & 12 & 38 & 256 & $24.0 \%$ & 19 & $7.4 \%$ & 0.67 \\
\hline $\begin{array}{l}\text { Eastern District } \\
\text { of Virginia }\end{array}$ & 14 & 32 & 373 & $30.4 \%$ & 24 & $6.4 \%$ & 0.96 \\
\hline $\begin{array}{l}\text { Southern } \\
\text { District of } \\
\text { Florida }\end{array}$ & 25 & 65 & 478 & $27.8 \%$ & 21 & $4.4 \%$ & 1.66 \\
\hline $\begin{array}{l}\text { Middle District } \\
\text { of Florida }\end{array}$ & 25 & 29 & 429 & $46.3 \%$ & 17 & $4.0 \%$ & 2.00 \\
\hline $\begin{array}{l}\text { District of } \\
\text { Delaware }\end{array}$ & 62 & 75 & 1017 & $45.3 \%$ & 120 & $11.8 \%$ & 2.03 \\
\hline $\begin{array}{l}\text { District of } \\
\text { Oregon }\end{array}$ & 19 & 23 & 251 & $45.2 \%$ & 8 & $3.2 \%$ & 2.07 \\
\hline $\begin{array}{l}\text { Eastern District } \\
\text { of Texas }\end{array}$ & 52 & 77 & 1024 & $40.3 \%$ & 82 & $8.0 \%$ & 2.13 \\
\hline $\begin{array}{l}\text { Western } \\
\text { District of } \\
\text { Washington }\end{array}$ & 11 & 44 & 392 & $20.0 \%$ & 3 & $0.8 \%$ & 2.19 \\
\hline $\begin{array}{l}\text { District of } \\
\text { Maryland }\end{array}$ & 7 & 21 & 242 & $25.0 \%$ & 6 & $2.5 \%$ & 2.22 \\
\hline $\begin{array}{l}\text { Northern } \\
\text { District of } \\
\text { Texas } \\
\end{array}$ & 27 & 22 & 405 & $55.1 \%$ & 10 & $2.5 \%$ & 2.26 \\
\hline $\begin{array}{l}\text { Southern } \\
\text { District of } \\
\text { Texas }\end{array}$ & 17 & 41 & 343 & $29.3 \%$ & 12 & $3.5 \%$ & 2.38 \\
\hline
\end{tabular}

15 See, e.g., Alisha Kay Taylor, Comment, What Does Forum Shopping in the Eastern District of Texas Mean for Patent Reform?, 6 J. MARSHALl ReV. INTELL. PROP. L. 570, 570 (2007). 


\begin{tabular}{|c|c|c|c|c|c|c|c|}
\hline $\begin{array}{l}\text { District of } \\
\text { Nevada }\end{array}$ & 24 & 28 & 198 & $46.2 \%$ & 5 & $2.5 \%$ & 2.39 \\
\hline $\begin{array}{l}\text { Central District } \\
\text { of California }\end{array}$ & 125 & 219 & 2289 & $36.3 \%$ & 35 & $1.5 \%$ & 2.47 \\
\hline $\begin{array}{l}\text { Southern } \\
\text { District of } \\
\text { California }\end{array}$ & 21 & 56 & 519 & $27.3 \%$ & 16 & $3.1 \%$ & 2.48 \\
\hline $\begin{array}{l}\text { Eastern District } \\
\text { of Missouri }\end{array}$ & 16 & 24 & 291 & $40.0 \%$ & 12 & $4.1 \%$ & 2.52 \\
\hline $\begin{array}{l}\text { Western } \\
\text { District of } \\
\text { Texas }\end{array}$ & 9 & 18 & 200 & $33.3 \%$ & 8 & $4.0 \%$ & 2.52 \\
\hline $\begin{array}{l}\text { Northern } \\
\text { District of } \\
\text { Illinois }\end{array}$ & 47 & 97 & 1233 & $32.6 \%$ & 20 & $1.6 \%$ & 2.52 \\
\hline $\begin{array}{l}\text { Northern } \\
\text { District of Ohio }\end{array}$ & 13 & 33 & 343 & $28.3 \%$ & 4 & $1.2 \%$ & 2.61 \\
\hline $\begin{array}{l}\text { District of } \\
\text { Massachusetts }\end{array}$ & 43 & 69 & 584 & $38.4 \%$ & 36 & $6.2 \%$ & 2.66 \\
\hline $\begin{array}{l}\text { Southern } \\
\text { District of New } \\
\text { York }\end{array}$ & 51 & 87 & 1018 & $37.0 \%$ & 16 & $1.6 \%$ & 2.85 \\
\hline $\begin{array}{l}\text { Northern } \\
\text { District of } \\
\text { California }\end{array}$ & 56 & 159 & 1424 & $26.0 \%$ & 44 & $3.1 \%$ & 2.92 \\
\hline $\begin{array}{l}\text { District of } \\
\text { Arizona }\end{array}$ & 10 & 23 & 271 & $30.3 \%$ & 7 & $2.6 \%$ & 2.95 \\
\hline $\begin{array}{l}\text { District of } \\
\text { Minnesota }\end{array}$ & 25 & 54 & 600 & $31.6 \%$ & 14 & $2.3 \%$ & 2.96 \\
\hline District of Utah & 15 & 39 & 357 & $27.8 \%$ & 2 & $0.6 \%$ & 2.99 \\
\hline $\begin{array}{l}\text { District of New } \\
\text { Jersey }\end{array}$ & 29 & 109 & 987 & $21.0 \%$ & 21 & $2.1 \%$ & 3.06 \\
\hline $\begin{array}{l}\text { Eastern District } \\
\text { of Pennsylvania }\end{array}$ & 15 & 40 & 475 & $27.3 \%$ & 7 & $1.5 \%$ & 3.09 \\
\hline $\begin{array}{l}\text { Northern } \\
\text { District of } \\
\text { Georgia } \\
\end{array}$ & 7 & 54 & 457 & $11.5 \%$ & 8 & $1.8 \%$ & 3.10 \\
\hline $\begin{array}{l}\text { District of } \\
\text { Colorado }\end{array}$ & 9 & 27 & 366 & $25.0 \%$ & 8 & $2.2 \%$ & 3.19 \\
\hline $\begin{array}{l}\text { Eastern District } \\
\text { of New York }\end{array}$ & 6 & 28 & 342 & $17.6 \%$ & 3 & $0.9 \%$ & 3.28 \\
\hline $\begin{array}{l}\text { Southern } \\
\text { District of Ohio }\end{array}$ & 8 & 22 & 218 & $26.7 \%$ & 1 & $0.5 \%$ & 3.30 \\
\hline
\end{tabular}




\begin{tabular}{|l|l|l|l|l|l|l|l|}
\hline $\begin{array}{l}\text { Eastern District } \\
\text { of Michigan }\end{array}$ & 18 & 54 & 514 & $25.0 \%$ & 11 & $2.1 \%$ & 3.41 \\
\hline $\begin{array}{l}\text { Eastern District } \\
\text { of Wisconsin }\end{array}$ & 7 & 34 & 241 & $17.1 \%$ & 2 & $0.8 \%$ & 3.51 \\
\hline $\begin{array}{l}\text { District of } \\
\text { Columbia }\end{array}$ & 9 & 25 & 115 & $26.5 \%$ & 0 & $0.0 \%$ & n/a \\
\hline
\end{tabular}

Not surprisingly, there are some similarities between time to resolution and time to trial, though the average time to trial is much longer than the average resolution, reflecting the prevalence of early settlements. The Western District of Wisconsin and the Eastern District of Virginia are truly rocket dockets; in those districts the average patent trial was completed less than a year after the case was filed. Notably, however, districts that are among the slowest to total resolution, including the Eastern District of Texas and the Northern District of California, are much faster than others when it comes to bringing cases to trial.

What is notable about all these measures is that no district court stands out as the best for plaintiffs or defendants on every measure. In other words, parties that want to forum shop must make tradeoffs.

To facilitate those tradeoffs, the following tables rank the districts by their aggregate standing on each of the possible measures: patentee win rate, the percentage of cases to trial, the time to resolution, and the time to trial. Table 7 presents a simple aggregate ranking, adding the rank of each district on each of the four measures. The lower the aggregate ranking number, the better the district is for patent plaintiffs; the higher the aggregate ranking, the better the 
district is for accused infringers. The magnitude of the numeric differences gives a coarse indication of how much more desirable one district is than another. ${ }^{16}$

Table 7: Aggregate Ranking of Districts

\begin{tabular}{|c|c|c|c|c|c|}
\hline مُّ & 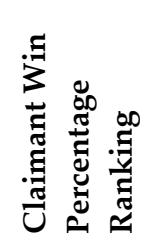 & 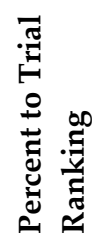 & 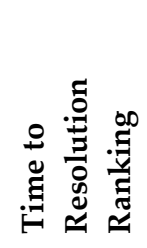 & 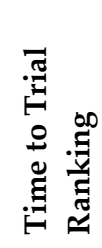 & 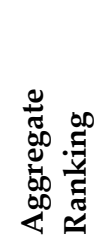 \\
\hline $\begin{array}{l}\text { Middle District } \\
\text { of Florida }\end{array}$ & 2 & 9 & 6 & 4 & 21 \\
\hline $\begin{array}{l}\text { Eastern District } \\
\text { of Virginia }\end{array}$ & 14 & 4 & 2 & 2 & 22 \\
\hline $\begin{array}{l}\text { District of } \\
\text { Delaware }\end{array}$ & 4 & 1 & 15 & 5 & 25 \\
\hline $\begin{array}{l}\text { Southern } \\
\text { District of } \\
\text { Florida }\end{array}$ & 18 & 6 & 4 & 3 & 31 \\
\hline $\begin{array}{l}\text { Western District } \\
\text { of Wisconsin }\end{array}$ & 28 & 3 & 1 & 1 & 33 \\
\hline $\begin{array}{l}\text { Northern } \\
\text { District of Texas }\end{array}$ & 1 & 17 & 10 & 10 & 38 \\
\hline $\begin{array}{l}\text { Eastern District } \\
\text { of Texas }\end{array}$ & 6 & 2 & 28 & 7 & 43 \\
\hline $\begin{array}{l}\text { Western District } \\
\text { of Texas }\end{array}$ & 11 & 8 & 11 & 16 & 46 \\
\hline District of & 5 & 11 & 25 & 6 & 47 \\
\hline
\end{tabular}

16 I ran a more sophisticated approach that compared the ratio of each district on each measure to the mean for that measure. That allows me to test the effect of the size of the difference between each district on the various measures. Doing so required inverting the ratio for the time to resolution and time to trial results, as lower numbers were desirable there. I have not reprinted the analysis because I think it distorts the results in favor of districts that happen to be outliers on measures with higher standard deviation (specifically, percentage to trial and time to trial), and creates other anomalies as well. For those nonetheless interested, the most favorable patentee jurisdictions on that analysis were the Western District of Wisconsin, the Eastern District of Virginia, the District of Delaware, the Eastern District of Texas, and the Middle District of Florida. The jurisdictions most favorable to accused infringers were the District of the District of Columbia, the Southern District of Ohio, the Eastern District of Wisconsin, the Eastern District of New York, and the District of Utah. 


\begin{tabular}{|c|c|c|c|c|c|}
\hline Oregon & & & & & \\
\hline $\begin{array}{l}\text { Eastern District } \\
\text { of Missouri }\end{array}$ & 7 & 7 & 18 & 15 & 47 \\
\hline $\begin{array}{l}\text { District of } \\
\text { Nevada }\end{array}$ & 3 & 15 & 19 & 12 & 49 \\
\hline $\begin{array}{l}\text { Southern } \\
\text { District of Texas }\end{array}$ & 16 & 10 & 16 & 11 & 53 \\
\hline $\begin{array}{l}\text { Central District } \\
\text { of California }\end{array}$ & 10 & 25 & 7 & 13 & 55 \\
\hline $\begin{array}{l}\text { Northern } \\
\text { District of } \\
\text { Illinois }\end{array}$ & 12 & 23 & 9 & 17 & 61 \\
\hline $\begin{array}{l}\text { Southern } \\
\text { District of } \\
\text { California } \\
\end{array}$ & 20 & 13 & 14 & 14 & 61 \\
\hline $\begin{array}{l}\text { District of } \\
\text { Maryland }\end{array}$ & 25 & 16 & 12 & 9 & 62 \\
\hline $\begin{array}{l}\text { District of } \\
\text { Massachusetts }\end{array}$ & 8 & 5 & 32 & 19 & 64 \\
\hline $\begin{array}{l}\text { Northern } \\
\text { District of Ohio }\end{array}$ & 17 & 27 & 8 & 18 & 70 \\
\hline $\begin{array}{l}\text { Western District } \\
\text { of Washington }\end{array}$ & 30 & 30 & 3 & 8 & 71 \\
\hline $\begin{array}{l}\text { Southern } \\
\text { District of New } \\
\text { York }\end{array}$ & 9 & 24 & 21 & 20 & 74 \\
\hline $\begin{array}{l}\text { District of } \\
\text { Colorado }\end{array}$ & 26 & 19 & 5 & 28 & 78 \\
\hline $\begin{array}{l}\text { District of } \\
\text { Minnesota }\end{array}$ & 13 & 18 & 26 & 23 & 80 \\
\hline $\begin{array}{l}\text { District of } \\
\text { Arizona }\end{array}$ & 15 & 14 & 31 & 22 & 82 \\
\hline $\begin{array}{l}\text { Northern } \\
\text { District of } \\
\text { California }\end{array}$ & 24 & 12 & 30 & 21 & 87 \\
\hline District of Utah & 19 & 31 & 17 & 24 & 91 \\
\hline $\begin{array}{l}\text { Northern } \\
\text { District of } \\
\text { Georgia }\end{array}$ & 33 & 22 & 13 & 27 & 95 \\
\hline $\begin{array}{l}\text { Eastern District } \\
\text { of Michigan }\end{array}$ & 27 & 20 & 20 & 31 & 98 \\
\hline $\begin{array}{l}\text { District of New } \\
\text { Jersey }\end{array}$ & 29 & 21 & 24 & 25 & 99 \\
\hline
\end{tabular}




\begin{tabular}{|l|l|l|l|l|l|}
\hline $\begin{array}{l}\text { Eastern District } \\
\text { of Pennsylvania }\end{array}$ & 21 & 26 & 33 & 26 & 106 \\
\hline $\begin{array}{l}\text { Eastern District } \\
\text { of New York }\end{array}$ & 31 & 28 & 22 & 29 & 110 \\
\hline $\begin{array}{l}\text { District of } \\
\text { Columbia }\end{array}$ & 23 & 33 & 23 & 33 & 112 \\
\hline $\begin{array}{l}\text { Southern } \\
\text { District of Ohio }\end{array}$ & 22 & 32 & 29 & 30 & 113 \\
\hline $\begin{array}{l}\text { Eastern District } \\
\text { of Wisconsin }\end{array}$ & 32 & 29 & 27 & 32 & 120 \\
\hline
\end{tabular}

The best aggregate patent district for plaintiffs is, surprisingly, the Middle District of Florida. As shown in Table 7 above, it is the only district that is in the top ten in every measure, with a ranking of two for claimant win percentage, nine for percentage of claims to trial, six for time to resolution, and four for time to trial. The other jurisdictions in the top five are somewhat less of a surprise: the Eastern District of Virginia, the District of Delaware, the Southern District of Florida, and the Western District of Wisconsin. What is surprising is that the Eastern District of Texas isn't in the five best districts for patent plaintiffs. On the accused infringer side, the most favorable jurisdictions are the Eastern District of Wisconsin, the Southern District of Ohio, the District of Columbia, the Eastern District of New York, and the Eastern District of Pennsylvania.

Aggregating rankings is, of course, a crude measure of how favorable a district is likely to be. Depending on a party's preferences, some of these districts might not look so favorable. For example, one of the top plaintiff's jurisdictions, the Western District of Wisconsin, actually ranks near the bottom in terms of patentee win rate. A patentee more concerned with winning than with speed would presumably not want to sue there. To account for these different preferences, Table 8 double counts the role of outcomes to present a rank ordering for an outcome-oriented plaintiff. The results do not change that much; the Northern District of Texas appears in the top five plaintiff jurisdictions, replacing the Western District of Wisconsin, and the Eastern District of Texas edges into the top five in a tie for fifth place. The District of New Jersey edges out the Eastern District of Pennsylvania as a prime jurisdiction for accused infringers. 
Table 8: Outcome-Emphasis Ranking of Districts with 25 or More Outcomes

\begin{tabular}{|c|c|c|c|c|c|}
\hline 菢 & 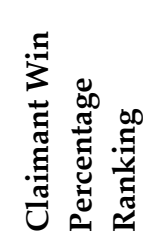 & 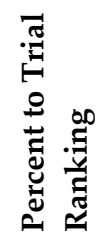 & 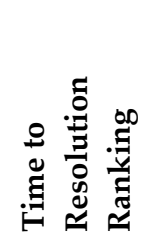 & 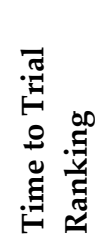 & 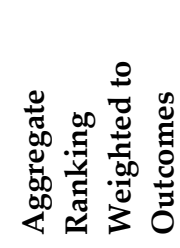 \\
\hline $\begin{array}{l}\text { Middle District } \\
\text { of Florida }\end{array}$ & 2 & 9 & 6 & 4 & 23 \\
\hline $\begin{array}{l}\text { District of } \\
\text { Delaware }\end{array}$ & 4 & 1 & 15 & 5 & 29 \\
\hline $\begin{array}{l}\text { Eastern District } \\
\text { of Virginia }\end{array}$ & 14 & 4 & 2 & 2 & 36 \\
\hline $\begin{array}{l}\text { Northern } \\
\text { District of Texas }\end{array}$ & 1 & 17 & 10 & 10 & 39 \\
\hline $\begin{array}{l}\text { Southern } \\
\text { District of } \\
\text { Florida }\end{array}$ & 18 & 6 & 4 & 3 & 49 \\
\hline $\begin{array}{l}\text { Eastern District } \\
\text { of Texas }\end{array}$ & 6 & 2 & 28 & 7 & 49 \\
\hline $\begin{array}{l}\text { District of } \\
\text { Oregon }\end{array}$ & 5 & 11 & 25 & 6 & 52 \\
\hline $\begin{array}{l}\text { District of } \\
\text { Nevada }\end{array}$ & 3 & 15 & 19 & 12 & 52 \\
\hline $\begin{array}{l}\text { Eastern District } \\
\text { of Missouri }\end{array}$ & 7 & 7 & 18 & 15 & 54 \\
\hline $\begin{array}{l}\text { Western District } \\
\text { of Texas }\end{array}$ & 11 & 8 & 11 & 16 & 57 \\
\hline $\begin{array}{l}\text { Western District } \\
\text { of Wisconsin }\end{array}$ & 28 & 3 & 1 & 1 & 61 \\
\hline $\begin{array}{l}\text { Central District } \\
\text { of California }\end{array}$ & 10 & 25 & 7 & 13 & 65 \\
\hline $\begin{array}{l}\text { Southern } \\
\text { District of Texas }\end{array}$ & 16 & 10 & 16 & 11 & 69 \\
\hline $\begin{array}{l}\text { District of } \\
\text { Massachusetts }\end{array}$ & 8 & 5 & 32 & 19 & 72 \\
\hline $\begin{array}{l}\text { Northern } \\
\text { District of } \\
\text { Illinois } \\
\end{array}$ & 12 & 23 & 9 & 17 & 73 \\
\hline $\begin{array}{l}\text { Southern } \\
\text { District of } \\
\text { California } \\
\end{array}$ & 20 & 13 & 14 & 14 & 81 \\
\hline $\begin{array}{l}\text { Southern } \\
\text { District of New }\end{array}$ & 9 & 24 & 21 & 20 & 83 \\
\hline
\end{tabular}




\begin{tabular}{|c|c|c|c|c|c|}
\hline York & & & & & \\
\hline $\begin{array}{l}\text { District of } \\
\text { Maryland }\end{array}$ & 25 & 16 & 12 & 9 & 87 \\
\hline $\begin{array}{l}\text { Northern } \\
\text { District of Ohio }\end{array}$ & 17 & 27 & 8 & 18 & 87 \\
\hline $\begin{array}{l}\text { District of } \\
\text { Minnesota }\end{array}$ & 13 & 18 & 26 & 23 & 93 \\
\hline $\begin{array}{l}\text { District of } \\
\text { Arizona }\end{array}$ & 15 & 14 & 31 & 22 & 97 \\
\hline $\begin{array}{l}\text { Western District } \\
\text { of Washington }\end{array}$ & 30 & 30 & 3 & 8 & 101 \\
\hline $\begin{array}{l}\text { District of } \\
\text { Colorado }\end{array}$ & 26 & 19 & 5 & 28 & 104 \\
\hline District of Utah & 19 & 31 & 17 & 24 & 110 \\
\hline $\begin{array}{l}\text { Northern } \\
\text { District of } \\
\text { California }\end{array}$ & 24 & 12 & 30 & 21 & 111 \\
\hline $\begin{array}{l}\text { Eastern District } \\
\text { of Michigan }\end{array}$ & 27 & 20 & 20 & 31 & 125 \\
\hline $\begin{array}{l}\text { Eastern District } \\
\text { of Pennsylvania }\end{array}$ & 21 & 26 & 33 & 26 & 127 \\
\hline $\begin{array}{l}\text { Northern } \\
\text { District of } \\
\text { Georgia }\end{array}$ & 33 & 22 & 13 & 27 & 128 \\
\hline $\begin{array}{l}\text { District of New } \\
\text { Jersey }\end{array}$ & 29 & 21 & 24 & 25 & 128 \\
\hline $\begin{array}{l}\text { District of } \\
\text { Columbia }\end{array}$ & 23 & 33 & 23 & 33 & 135 \\
\hline $\begin{array}{l}\text { Southern } \\
\text { District of Ohio }\end{array}$ & 22 & 32 & 29 & 30 & 135 \\
\hline $\begin{array}{l}\text { Eastern District } \\
\text { of New York }\end{array}$ & 31 & 28 & 22 & 29 & 141 \\
\hline $\begin{array}{l}\text { Eastern District } \\
\text { of Wisconsin }\end{array}$ & 32 & 29 & 27 & 32 & 152 \\
\hline
\end{tabular}

Perhaps plaintiffs have other preferences. Table 9 shows the ranking for a plaintiff particularly interested in getting to trial, double-counting both the percentage of cases that go to trial and the time to trial. The order of the top five patentee jurisdictions changes, with the Eastern District of Virginia topping the list, but the top five stay the same. The same is true of the top five accused infringer jurisdictions. 
Table 9: Trial-Emphasis Ranking of Districts with 25 or More Outcomes

\begin{tabular}{|c|c|c|c|c|c|}
\hline 苐 & 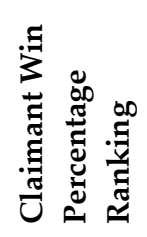 & 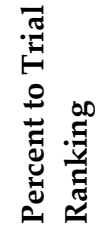 & 泀 & 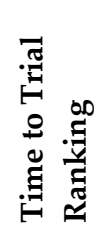 & 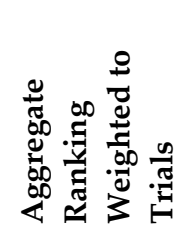 \\
\hline $\begin{array}{l}\text { Eastern District } \\
\text { of Virginia }\end{array}$ & 14 & 4 & 2 & 2 & 28 \\
\hline $\begin{array}{l}\text { District of } \\
\text { Delaware }\end{array}$ & 4 & 1 & 15 & 5 & 31 \\
\hline $\begin{array}{l}\text { Middle District } \\
\text { of Florida }\end{array}$ & 2 & 9 & 6 & 4 & 34 \\
\hline $\begin{array}{l}\text { Western District } \\
\text { of Wisconsin }\end{array}$ & 28 & 3 & 1 & 1 & 37 \\
\hline $\begin{array}{l}\text { Southern } \\
\text { District of } \\
\text { Florida }\end{array}$ & 18 & 6 & 4 & 3 & 40 \\
\hline $\begin{array}{l}\text { Eastern District } \\
\text { of Texas }\end{array}$ & 6 & 2 & 28 & 7 & 52 \\
\hline $\begin{array}{l}\text { District of } \\
\text { Oregon }\end{array}$ & 5 & 11 & 25 & 6 & 64 \\
\hline $\begin{array}{l}\text { Northern } \\
\text { District of Texas }\end{array}$ & 1 & 17 & 10 & 10 & 65 \\
\hline $\begin{array}{l}\text { Eastern District } \\
\text { of Missouri }\end{array}$ & 7 & 7 & 18 & 15 & 69 \\
\hline $\begin{array}{l}\text { Western District } \\
\text { of Texas }\end{array}$ & 11 & 8 & 11 & 16 & 70 \\
\hline $\begin{array}{l}\text { Southern } \\
\text { District of Texas }\end{array}$ & 16 & 10 & 16 & 11 & 74 \\
\hline $\begin{array}{l}\text { District of } \\
\text { Nevada }\end{array}$ & 3 & 15 & 19 & 12 & 76 \\
\hline $\begin{array}{l}\text { District of } \\
\text { Maryland }\end{array}$ & 25 & 16 & 12 & 9 & 87 \\
\hline $\begin{array}{l}\text { District of } \\
\text { Massachusetts } \\
\end{array}$ & 8 & 5 & 32 & 19 & 88 \\
\hline $\begin{array}{l}\text { Southern } \\
\text { District of } \\
\text { California }\end{array}$ & 20 & 13 & 14 & 14 & 88 \\
\hline $\begin{array}{l}\text { Central District } \\
\text { of California }\end{array}$ & 10 & 25 & 7 & 13 & 93 \\
\hline $\begin{array}{l}\text { Northern } \\
\text { District of }\end{array}$ & 12 & 23 & 9 & 17 & 101 \\
\hline
\end{tabular}




\begin{tabular}{|c|c|c|c|c|c|}
\hline Illinois & & & & & \\
\hline $\begin{array}{l}\text { Western District } \\
\text { of Washington }\end{array}$ & 30 & 30 & 3 & 8 & 109 \\
\hline $\begin{array}{l}\text { Northern } \\
\text { District of Ohio }\end{array}$ & 17 & 27 & 8 & 18 & 115 \\
\hline $\begin{array}{l}\text { Southern } \\
\text { District of New } \\
\text { York }\end{array}$ & 9 & 24 & 21 & 20 & 118 \\
\hline $\begin{array}{l}\text { District of } \\
\text { Arizona }\end{array}$ & 15 & 14 & 31 & 22 & 118 \\
\hline $\begin{array}{l}\text { Northern } \\
\text { District of } \\
\text { California }\end{array}$ & 24 & 12 & 30 & 21 & 120 \\
\hline $\begin{array}{l}\text { District of } \\
\text { Minnesota }\end{array}$ & 13 & 18 & 26 & 23 & 121 \\
\hline $\begin{array}{l}\text { District of } \\
\text { Colorado }\end{array}$ & 26 & 19 & 5 & 28 & 125 \\
\hline $\begin{array}{l}\text { Northern } \\
\text { District of } \\
\text { Georgia }\end{array}$ & 33 & 22 & 13 & 27 & 144 \\
\hline $\begin{array}{l}\text { District of New } \\
\text { Jersey }\end{array}$ & 29 & 21 & 24 & 25 & 145 \\
\hline District of Utah & 19 & 31 & 17 & 24 & 146 \\
\hline $\begin{array}{l}\text { Eastern District } \\
\text { of Michigan }\end{array}$ & 27 & 20 & 20 & 31 & 149 \\
\hline $\begin{array}{l}\text { Eastern District } \\
\text { of Pennsylvania }\end{array}$ & 21 & 26 & 33 & 26 & 158 \\
\hline $\begin{array}{l}\text { Eastern District } \\
\text { of New York }\end{array}$ & 31 & 28 & 22 & 29 & 167 \\
\hline $\begin{array}{l}\text { Southern } \\
\text { District of Ohio }\end{array}$ & 22 & 32 & 29 & 30 & 175 \\
\hline $\begin{array}{l}\text { District of } \\
\text { Columbia }\end{array}$ & 23 & 33 & 23 & 33 & 178 \\
\hline $\begin{array}{l}\text { Eastern District } \\
\text { of Wisconsin }\end{array}$ & 32 & 29 & 27 & 32 & 181 \\
\hline
\end{tabular}

Finally, Table 10 shows the results for a plaintiff interested only in speed, double-weighting time to resolution and time to trial. Once again the top five districts for both patentees and accused infringers change their order but remain the same. Notably, by this measure the Eastern District of Texas drops to ninth place, behind the Central District of California. 
Table 10: Speed-Emphasis Ranking of Districts with 25 or More Outcomes

\begin{tabular}{|c|c|c|c|c|c|}
\hline 泀 & 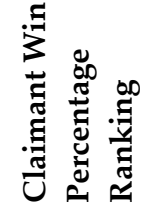 & 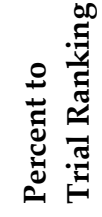 & 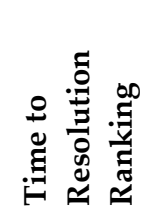 & 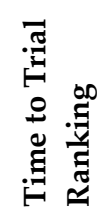 & 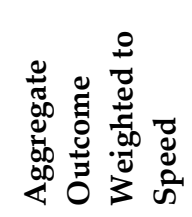 \\
\hline $\begin{array}{l}\text { Eastern District } \\
\text { of Virginia }\end{array}$ & 14 & 4 & 2 & 2 & 26 \\
\hline $\begin{array}{l}\text { Middle District } \\
\text { of Florida }\end{array}$ & 2 & 9 & 6 & 4 & 31 \\
\hline $\begin{array}{l}\text { Western District } \\
\text { of Wisconsin }\end{array}$ & 28 & 3 & 1 & 1 & 35 \\
\hline $\begin{array}{l}\text { Southern } \\
\text { District of } \\
\text { Florida }\end{array}$ & 18 & 6 & 4 & 3 & 38 \\
\hline $\begin{array}{l}\text { District of } \\
\text { Delaware }\end{array}$ & 4 & 1 & 15 & 5 & 45 \\
\hline $\begin{array}{l}\text { Northern } \\
\text { District of Texas }\end{array}$ & 1 & 17 & 10 & 10 & 58 \\
\hline $\begin{array}{l}\text { Western District } \\
\text { of Texas }\end{array}$ & 11 & 8 & 11 & 16 & 73 \\
\hline $\begin{array}{l}\text { Central District } \\
\text { of California }\end{array}$ & 10 & 25 & 7 & 13 & 75 \\
\hline $\begin{array}{l}\text { Eastern District } \\
\text { of Texas }\end{array}$ & 6 & 2 & 28 & 7 & 78 \\
\hline $\begin{array}{l}\text { District of } \\
\text { Oregon }\end{array}$ & 5 & 11 & 25 & 6 & 78 \\
\hline $\begin{array}{l}\text { Eastern District } \\
\text { of Missouri }\end{array}$ & 7 & 7 & 18 & 15 & 80 \\
\hline $\begin{array}{l}\text { Southern } \\
\text { District of Texas }\end{array}$ & 16 & 10 & 16 & 11 & 80 \\
\hline $\begin{array}{l}\text { District of } \\
\text { Nevada }\end{array}$ & 3 & 15 & 19 & 12 & 80 \\
\hline $\begin{array}{l}\text { Western District } \\
\text { of Washington }\end{array}$ & 30 & 30 & 3 & 8 & 82 \\
\hline $\begin{array}{l}\text { District of } \\
\text { Maryland }\end{array}$ & 25 & 16 & 12 & 9 & 83 \\
\hline $\begin{array}{l}\text { Northern } \\
\text { District of } \\
\text { Illinois } \\
\end{array}$ & 12 & 23 & 9 & 17 & 87 \\
\hline $\begin{array}{l}\text { Southern } \\
\text { District of }\end{array}$ & 20 & 13 & 14 & 14 & 89 \\
\hline
\end{tabular}




\begin{tabular}{|c|c|c|c|c|c|}
\hline California & & & & & \\
\hline $\begin{array}{l}\text { Northern } \\
\text { District of Ohio }\end{array}$ & 17 & 27 & 8 & 18 & 96 \\
\hline $\begin{array}{l}\text { District of } \\
\text { Colorado }\end{array}$ & 26 & 19 & 5 & 28 & 111 \\
\hline $\begin{array}{l}\text { District of } \\
\text { Massachusetts }\end{array}$ & 8 & 5 & 32 & 19 & 115 \\
\hline $\begin{array}{l}\text { Southern } \\
\text { District of New } \\
\text { York }\end{array}$ & 9 & 24 & 21 & 20 & 115 \\
\hline $\begin{array}{l}\text { District of } \\
\text { Minnesota }\end{array}$ & 13 & 18 & 26 & 23 & 129 \\
\hline District of Utah & 19 & 31 & 17 & 24 & 132 \\
\hline $\begin{array}{l}\text { District of } \\
\text { Arizona }\end{array}$ & 15 & 14 & 31 & 22 & 135 \\
\hline $\begin{array}{l}\text { Northern } \\
\text { District of } \\
\text { Georgia } \\
\end{array}$ & 33 & 22 & 13 & 27 & 135 \\
\hline $\begin{array}{l}\text { Northern } \\
\text { District of } \\
\text { California }\end{array}$ & 24 & 12 & 30 & 21 & 138 \\
\hline $\begin{array}{l}\text { District of New } \\
\text { Jersey }\end{array}$ & 29 & 21 & 24 & 25 & 148 \\
\hline $\begin{array}{l}\text { Eastern District } \\
\text { of Michigan }\end{array}$ & 27 & 20 & 20 & 31 & 149 \\
\hline $\begin{array}{l}\text { Eastern District } \\
\text { of New York }\end{array}$ & 31 & 28 & 22 & 29 & 161 \\
\hline $\begin{array}{l}\text { Eastern District } \\
\text { of Pennsylvania }\end{array}$ & 21 & 26 & 33 & 26 & 165 \\
\hline $\begin{array}{l}\text { District of } \\
\text { Columbia }\end{array}$ & 23 & 33 & 23 & 33 & 168 \\
\hline $\begin{array}{l}\text { Southern } \\
\text { District of Ohio }\end{array}$ & 22 & 32 & 29 & 30 & 172 \\
\hline $\begin{array}{l}\text { Eastern District } \\
\text { of Wisconsin }\end{array}$ & 32 & 29 & 27 & 32 & 179 \\
\hline
\end{tabular}

The results, in short, seem fairly stable across a variety of likely preferences, and they reflect received wisdom only in part. Accused infringers should be trying to litigate in the Eastern District of Wisconsin, the Southern District of Ohio, or the District of Columbia, none of which are currently on the radar screen of most patent lawyers. Patentees should be suing in a variety of districts, including the District of Delaware, the Eastern District of Virginia, and 
the Western District of Wisconsin. Virginia and Wisconsin aren't much of a surprise, but patent lawyers seem to overvalue the Eastern District of Texas and undervalue the District of Delaware. ${ }^{17}$ And as for the best-and least appreciated-jurisdiction for patent plaintiffs? Let's put it this way:

Q: “Mark, you've just completed an exhaustive study of where to file your patent suit. What are you going to do now?"

A: "I'm going to Disney World."

17 But cf. John E. Kidd \& Keeto H. Sabharwal, The District of Delaware: An Ideal Venue for Patent Litigators, 18 DeL. LAW. 16, 17 (2000) (explaining why the Delaware District court is an ideal venue for patent plaintiffs). 
Appendix A

Patent Litigation Outcomes by Court

\begin{tabular}{|c|c|c|c|c|c|c|c|c|}
\hline \multirow{2}{*}{$\begin{array}{l}\text { Court } \\
\text { First Circuit }\end{array}$} & \multicolumn{6}{|c|}{ Outcomes } & \multirow[b]{2}{*}{ 岕 } & \multirow[b]{2}{*}{ 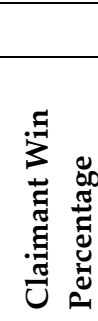 } \\
\hline & 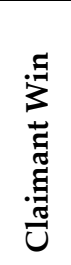 & 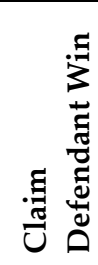 & 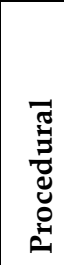 & 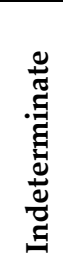 & 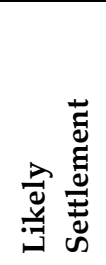 & 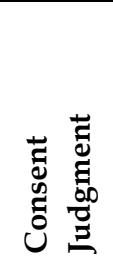 & & \\
\hline $\begin{array}{l}\text { District of } \\
\text { Maine }\end{array}$ & 0 & 3 & 1 & 0 & 19 & 2 & 25 & $0.0 \%$ \\
\hline $\begin{array}{l}\text { District of } \\
\text { Massachusetts }\end{array}$ & 43 & 69 & 41 & 1 & 392 & 38 & 584 & $38.4 \%$ \\
\hline $\begin{array}{l}\text { District of New } \\
\text { Hampshire }\end{array}$ & 5 & 11 & 6 & 0 & 45 & 6 & 73 & $31.3 \%$ \\
\hline $\begin{array}{l}\text { District of } \\
\text { Rhode Island }\end{array}$ & 5 & 6 & 5 & 0 & 38 & 4 & 58 & $45.5 \%$ \\
\hline $\begin{array}{l}\text { District of } \\
\text { Puerto Rico }\end{array}$ & 0 & 2 & 3 & 0 & 4 & 1 & 10 & $0.0 \%$ \\
\hline Subtotal & 53 & 91 & 56 & 1 & 498 & 51 & 750 & $36.8 \%$ \\
\hline Second Circuit & 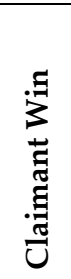 & 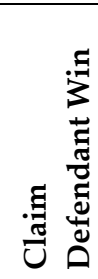 & 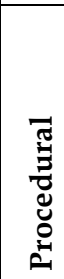 & 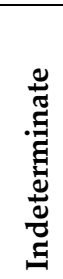 & 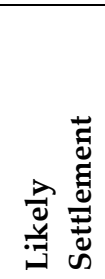 & 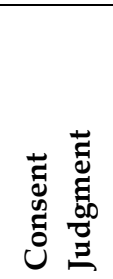 & 嵌 & 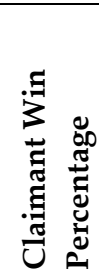 \\
\hline $\begin{array}{l}\text { District of } \\
\text { Connecticut }\end{array}$ & 4 & 17 & 21 & 0 & 209 & 27 & 278 & $19.0 \%$ \\
\hline $\begin{array}{l}\text { Northern } \\
\text { District of New } \\
\text { York }\end{array}$ & 4 & 2 & 4 & 0 & 76 & 7 & 93 & $66.7 \%$ \\
\hline $\begin{array}{l}\text { Eastern District } \\
\text { of New York }\end{array}$ & 6 & 28 & 29 & 0 & 245 & 34 & 342 & $17.6 \%$ \\
\hline $\begin{array}{l}\text { Southern } \\
\text { District of New } \\
\text { York }\end{array}$ & 51 & 87 & 87 & 1 & 676 & 116 & 1018 & $37.0 \%$ \\
\hline $\begin{array}{l}\text { Western } \\
\text { District of New } \\
\text { York }\end{array}$ & 4 & 10 & 17 & 0 & 122 & 10 & 163 & $28.6 \%$ \\
\hline
\end{tabular}




\begin{tabular}{|c|c|c|c|c|c|c|c|c|}
\hline $\begin{array}{l}\text { District of } \\
\text { Vermont }\end{array}$ & 1 & 0 & 3 & 0 & 18 & 1 & 23 & $100.0 \%$ \\
\hline Subtotal & 70 & 144 & 161 & 1 & 1346 & 195 & 1917 & $32.7 \%$ \\
\hline Third Circuit & 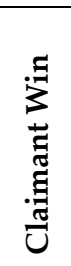 & 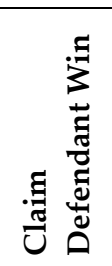 & 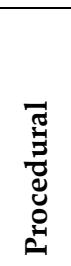 & 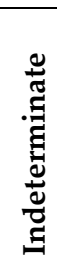 & 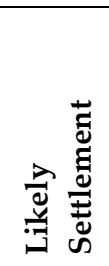 & 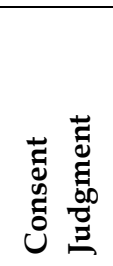 & 它 & 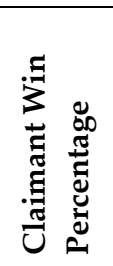 \\
\hline $\begin{array}{l}\text { District of } \\
\text { Delaware }\end{array}$ & 62 & 75 & 137 & 0 & 682 & 61 & 1017 & $45.3 \%$ \\
\hline $\begin{array}{l}\text { District of New } \\
\text { Jersey }\end{array}$ & 29 & 109 & 201 & 0 & 588 & 60 & 987 & $21.0 \%$ \\
\hline $\begin{array}{l}\text { Eastern District } \\
\text { of Pennsylvania }\end{array}$ & 15 & 40 & 42 & 3 & 342 & 33 & 475 & $27.3 \%$ \\
\hline $\begin{array}{l}\text { Middle District } \\
\text { of Pennsylvania }\end{array}$ & 6 & 1 & 5 & 1 & 33 & 8 & 54 & $85.7 \%$ \\
\hline $\begin{array}{l}\text { Western } \\
\text { District of } \\
\text { Pennsylvania }\end{array}$ & 5 & 18 & 21 & 0 & 123 & 14 & 181 & $21.7 \%$ \\
\hline $\begin{array}{l}\text { District of } \\
\text { Virgin Islands }\end{array}$ & 0 & 0 & 0 & 0 & 0 & 0 & 0 & N/A \\
\hline Subtotal & 117 & 243 & 406 & 4 & 1768 & 176 & 2714 & $32.5 \%$ \\
\hline Fourth Circuit & 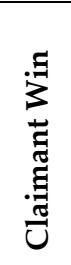 & 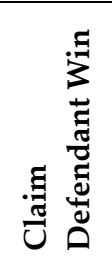 & 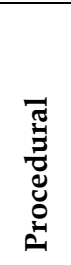 & 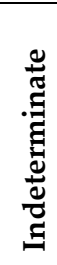 & 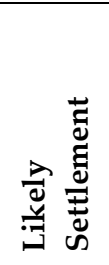 & 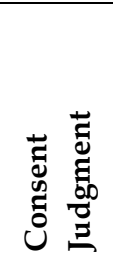 & 峁 & 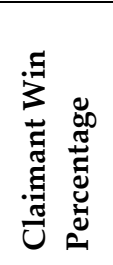 \\
\hline $\begin{array}{l}\text { District of } \\
\text { Maryland }\end{array}$ & 7 & 21 & 40 & 0 & 161 & 13 & 242 & $25.0 \%$ \\
\hline $\begin{array}{l}\text { Eastern District } \\
\text { of North } \\
\text { Carolina }\end{array}$ & 3 & 8 & 3 & 0 & 47 & 11 & 72 & $27.3 \%$ \\
\hline $\begin{array}{l}\text { Middle District } \\
\text { of North } \\
\text { Carolina }\end{array}$ & 6 & 10 & 5 & 0 & 106 & 23 & 150 & $37.5 \%$ \\
\hline $\begin{array}{l}\text { Western } \\
\text { District of } \\
\text { North Carolina }\end{array}$ & 5 & 7 & 9 & 0 & 117 & 15 & 153 & $41.7 \%$ \\
\hline
\end{tabular}




\begin{tabular}{|c|c|c|c|c|c|c|c|c|}
\hline $\begin{array}{l}\text { District of } \\
\text { South Carolina }\end{array}$ & 5 & 15 & 11 & 0 & 88 & 12 & 131 & $25.0 \%$ \\
\hline $\begin{array}{l}\text { Eastern District } \\
\text { of Virginia }\end{array}$ & 14 & 32 & 69 & 1 & 229 & 28 & 373 & $30.4 \%$ \\
\hline $\begin{array}{l}\text { Western } \\
\text { District of } \\
\text { Virginia }\end{array}$ & 2 & 6 & 4 & 0 & 31 & 1 & 44 & $25.0 \%$ \\
\hline $\begin{array}{l}\text { Northern } \\
\text { District of West } \\
\text { Virginia }\end{array}$ & 2 & 1 & 6 & 0 & 16 & 4 & 29 & $66.7 \%$ \\
\hline $\begin{array}{l}\text { Southern } \\
\text { District of West } \\
\text { Virginia }\end{array}$ & 0 & 2 & 1 & 0 & 4 & 0 & 7 & $0.0 \%$ \\
\hline Subtotal & 44 & 102 & 148 & 1 & 799 & 107 & 1201 & $30.1 \%$ \\
\hline Fifth Circuit & 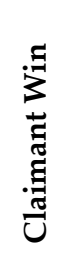 & مَ & 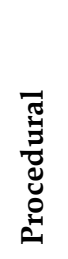 & 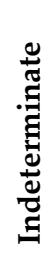 & 常 & 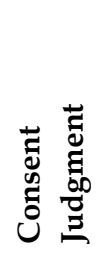 & 幽 & 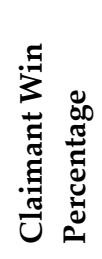 \\
\hline $\begin{array}{l}\text { Western } \\
\text { District of } \\
\text { Louisiana }\end{array}$ & 2 & 5 & 4 & 0 & 39 & 3 & 53 & $28.6 \%$ \\
\hline $\begin{array}{l}\text { Northern } \\
\text { District of } \\
\text { Mississippi }\end{array}$ & 0 & 1 & 3 & 0 & 6 & 1 & 11 & $0.0 \%$ \\
\hline $\begin{array}{l}\text { Southern } \\
\text { District of } \\
\text { Mississippi }\end{array}$ & 0 & 5 & 4 & 0 & 5 & 2 & 16 & $0.0 \%$ \\
\hline $\begin{array}{l}\text { Northern } \\
\text { District of } \\
\text { Texas }\end{array}$ & 27 & 22 & 55 & 0 & 283 & 18 & 405 & $55.1 \%$ \\
\hline $\begin{array}{l}\text { Eastern District } \\
\text { of Texas }\end{array}$ & 52 & 77 & 150 & 0 & 703 & 42 & 1024 & $40.3 \%$ \\
\hline $\begin{array}{l}\text { Southern } \\
\text { District of } \\
\text { Texas } \\
\end{array}$ & 17 & 41 & 51 & 2 & 214 & 18 & 343 & $29.3 \%$ \\
\hline $\begin{array}{l}\text { Western } \\
\text { District of } \\
\text { Texas }\end{array}$ & 9 & 18 & 17 & 0 & 151 & 5 & 200 & $33.3 \%$ \\
\hline $\begin{array}{l}\text { Eastern District } \\
\text { of Louisiana }\end{array}$ & 3 & 1 & 17 & 0 & 53 & 13 & 87 & $75.0 \%$ \\
\hline
\end{tabular}




\begin{tabular}{|c|c|c|c|c|c|c|c|c|}
\hline $\begin{array}{l}\text { Middle District } \\
\text { of Louisiana }\end{array}$ & 0 & 0 & 4 & 0 & 13 & 0 & 17 & N/A \\
\hline Subtotal & 110 & 170 & 305 & 2 & 1467 & 102 & 2156 & $39.3 \%$ \\
\hline Sixth Circuit & 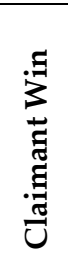 & छ & 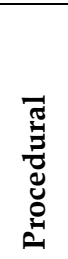 & & 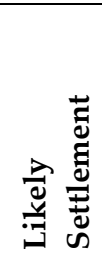 & 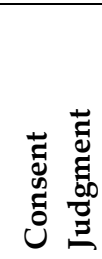 & 胥 & 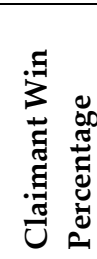 \\
\hline $\begin{array}{l}\text { Eastern District } \\
\text { of Kentucky }\end{array}$ & 2 & 5 & 6 & 0 & 29 & 2 & 44 & $28.6 \%$ \\
\hline $\begin{array}{l}\text { Western } \\
\text { District of } \\
\text { Kentucky }\end{array}$ & 2 & 1 & 1 & 0 & 40 & 3 & 47 & $66.7 \%$ \\
\hline $\begin{array}{l}\text { Eastern District } \\
\text { of Michigan }\end{array}$ & 18 & 54 & 34 & 0 & 378 & 30 & 514 & $25.0 \%$ \\
\hline $\begin{array}{l}\text { Western } \\
\text { District of } \\
\text { Michigan } \\
\end{array}$ & 6 & 15 & 9 & 0 & 110 & 12 & 152 & $28.6 \%$ \\
\hline $\begin{array}{l}\text { Northern } \\
\text { District of Ohio }\end{array}$ & 13 & 33 & 14 & 0 & 268 & 15 & 343 & $28.3 \%$ \\
\hline $\begin{array}{l}\text { Southern } \\
\text { District of Ohio }\end{array}$ & 8 & 22 & 23 & 0 & 149 & 16 & 218 & $26.7 \%$ \\
\hline $\begin{array}{l}\text { Eastern District } \\
\text { of Tennessee }\end{array}$ & 3 & 3 & 4 & 0 & 33 & 3 & 46 & $50.0 \%$ \\
\hline $\begin{array}{l}\text { Middle District } \\
\text { of Tennessee }\end{array}$ & 5 & 7 & 7 & 1 & 43 & 2 & 65 & $41.7 \%$ \\
\hline $\begin{array}{l}\text { Western } \\
\text { District of } \\
\text { Tennessee }\end{array}$ & 5 & 4 & 9 & 0 & 33 & 14 & 65 & $55.6 \%$ \\
\hline Subtotal & 62 & 144 & 107 & 1 & 1083 & 97 & 1494 & $30.1 \%$ \\
\hline Seventh Circuit & 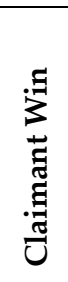 & 音 & 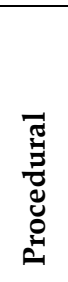 & & 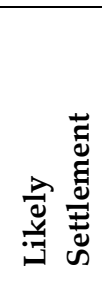 & 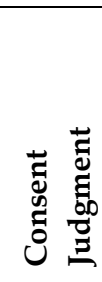 & 岂 & 疍 \\
\hline $\begin{array}{l}\text { Northern } \\
\text { District of } \\
\text { Illinois }\end{array}$ & 47 & 97 & 119 & 3 & 874 & 93 & 1233 & $32.6 \%$ \\
\hline
\end{tabular}




\begin{tabular}{|c|c|c|c|c|c|c|c|c|}
\hline $\begin{array}{l}\text { Central District } \\
\text { of Illinois }\end{array}$ & 6 & 4 & 2 & 0 & 37 & 8 & 57 & $60.0 \%$ \\
\hline $\begin{array}{l}\text { Southern } \\
\text { District of } \\
\text { Illinois }\end{array}$ & 0 & 2 & 3 & 0 & 14 & 4 & 23 & $0.0 \%$ \\
\hline $\begin{array}{l}\text { Northern } \\
\text { District of } \\
\text { Indiana }\end{array}$ & 0 & 9 & 7 & 0 & 72 & 13 & 101 & $0.0 \%$ \\
\hline $\begin{array}{l}\text { Southern } \\
\text { District of } \\
\text { Indiana } \\
\end{array}$ & 7 & 7 & 22 & 0 & 106 & 10 & 152 & $50.0 \%$ \\
\hline $\begin{array}{l}\text { Eastern District } \\
\text { of Wisconsin }\end{array}$ & 7 & 34 & 21 & 0 & 162 & 17 & 241 & $17.1 \%$ \\
\hline $\begin{array}{l}\text { Western } \\
\text { District of } \\
\text { Wisconsin }\end{array}$ & 12 & 38 & 31 & 2 & 155 & 18 & 256 & $24.0 \%$ \\
\hline Subtotal & 79 & 191 & 205 & 5 & 1420 & 163 & 2063 & $29.3 \%$ \\
\hline Eighth Circuit & 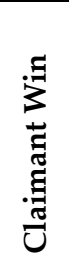 & 刍 & 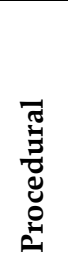 & 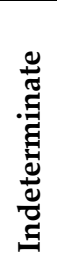 & 泀 & 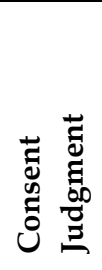 & 必 & 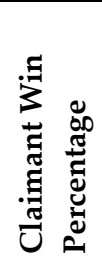 \\
\hline $\begin{array}{l}\text { Eastern District } \\
\text { of Arkansas }\end{array}$ & 3 & 3 & 1 & 0 & 14 & 10 & 31 & $50.0 \%$ \\
\hline $\begin{array}{l}\text { Western } \\
\text { District of } \\
\text { Arkansas } \\
\end{array}$ & 1 & 2 & 1 & 0 & 14 & 3 & 21 & $33.3 \%$ \\
\hline $\begin{array}{l}\text { Northern } \\
\text { District of Iowa }\end{array}$ & 3 & 2 & 0 & 0 & 17 & 1 & 23 & $60.0 \%$ \\
\hline $\begin{array}{l}\text { Southern } \\
\text { District of Iowa }\end{array}$ & 7 & 7 & 2 & 0 & 52 & 10 & 78 & $50.0 \%$ \\
\hline $\begin{array}{l}\text { District of } \\
\text { Minnesota }\end{array}$ & 25 & 54 & 28 & 0 & 450 & 43 & 600 & $31.6 \%$ \\
\hline $\begin{array}{l}\text { Eastern District } \\
\text { of Missouri }\end{array}$ & 16 & 24 & 26 & 0 & 170 & 55 & 291 & $40.0 \%$ \\
\hline $\begin{array}{l}\text { Western } \\
\text { District of } \\
\text { Missouri } \\
\end{array}$ & 5 & 12 & 3 & 0 & 69 & 8 & 97 & $29.4 \%$ \\
\hline $\begin{array}{l}\text { District of } \\
\text { Nebraska }\end{array}$ & 2 & 7 & 3 & 0 & 47 & 5 & 64 & $22.2 \%$ \\
\hline $\begin{array}{l}\text { District of } \\
\text { North Dakota } \\
\end{array}$ & 1 & 2 & 4 & 0 & 13 & 1 & 21 & $33.3 \%$ \\
\hline
\end{tabular}




\begin{tabular}{|c|c|c|c|c|c|c|c|c|}
\hline $\begin{array}{l}\text { District of } \\
\text { South Dakota }\end{array}$ & 0 & 0 & 0 & 0 & 9 & 2 & 11 & N/A \\
\hline Subtotal & 63 & 113 & 68 & 0 & 855 & 138 & 1237 & $35.8 \%$ \\
\hline Ninth Circuit & 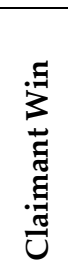 & פ & 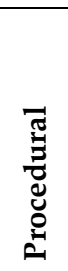 & 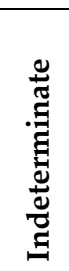 & 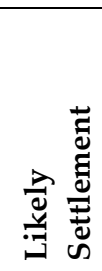 & 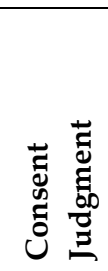 & 岕 & 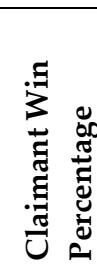 \\
\hline $\begin{array}{l}\text { District of } \\
\text { Arizona }\end{array}$ & 10 & 23 & 28 & 0 & 193 & 17 & 271 & $30.3 \%$ \\
\hline $\begin{array}{l}\text { Northern } \\
\text { District of } \\
\text { California }\end{array}$ & 56 & 159 & 131 & 0 & 1007 & 71 & 1424 & $26.0 \%$ \\
\hline $\begin{array}{l}\text { Eastern District } \\
\text { of California }\end{array}$ & 8 & 16 & 6 & 2 & 64 & 8 & 104 & $33.3 \%$ \\
\hline $\begin{array}{l}\text { Central District } \\
\text { of California }\end{array}$ & 125 & 219 & 193 & 11 & 1401 & 340 & 2289 & $36.3 \%$ \\
\hline $\begin{array}{l}\text { Southern } \\
\text { District of } \\
\text { California }\end{array}$ & 21 & 56 & 24 & 1 & 380 & 37 & 519 & $27.3 \%$ \\
\hline $\begin{array}{l}\text { District of } \\
\text { Hawaii }\end{array}$ & 4 & 3 & 1 & 0 & 17 & 9 & 34 & $57.1 \%$ \\
\hline $\begin{array}{l}\text { District of } \\
\text { Idaho }\end{array}$ & 6 & 3 & 0 & 0 & 28 & 3 & 40 & $66.7 \%$ \\
\hline $\begin{array}{l}\text { District of } \\
\text { Montana }\end{array}$ & 2 & 2 & 2 & 1 & 10 & 1 & 18 & $50.0 \%$ \\
\hline $\begin{array}{l}\text { District of } \\
\text { Nevada }\end{array}$ & 24 & 28 & 15 & 0 & 117 & 14 & 198 & $46.2 \%$ \\
\hline $\begin{array}{l}\text { District of } \\
\text { Oregon }\end{array}$ & 19 & 23 & 8 & 0 & 160 & 41 & 251 & $45.2 \%$ \\
\hline $\begin{array}{l}\text { Eastern District } \\
\text { of Washington }\end{array}$ & 0 & 12 & 4 & 0 & 35 & 7 & 58 & $0.0 \%$ \\
\hline $\begin{array}{l}\text { Western } \\
\text { District of } \\
\text { Washington }\end{array}$ & 11 & 44 & 56 & 0 & 248 & 33 & 392 & $20.0 \%$ \\
\hline $\begin{array}{l}\text { District of } \\
\text { Guam }\end{array}$ & 0 & 0 & 1 & 0 & 0 & 0 & 1 & $\mathrm{~N} / \mathrm{A}$ \\
\hline $\begin{array}{l}\text { District of } \\
\text { Northern } \\
\text { Mariana } \\
\text { Islands }\end{array}$ & 0 & 0 & 0 & 0 & 0 & 0 & 0 & N/A \\
\hline
\end{tabular}




\begin{tabular}{|c|c|c|c|c|c|c|c|c|}
\hline $\begin{array}{l}\text { District of } \\
\text { Alaska }\end{array}$ & 0 & 0 & 0 & 0 & 1 & 0 & 1 & N/A \\
\hline Subtotal & 286 & 588 & 469 & 15 & 3661 & 581 & 5600 & $32.7 \%$ \\
\hline Tenth Circuit & 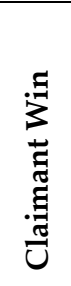 & 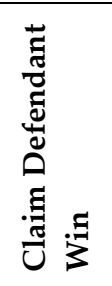 & 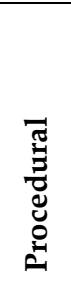 & 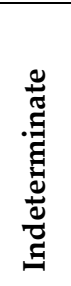 & 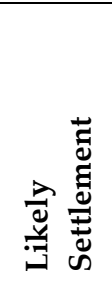 & 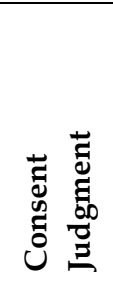 & 它 & 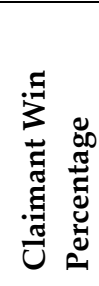 \\
\hline $\begin{array}{l}\text { District of } \\
\text { Colorado }\end{array}$ & 9 & 27 & 28 & 0 & 285 & 17 & 366 & $25.0 \%$ \\
\hline $\begin{array}{l}\text { District of } \\
\text { Kansas } \\
\end{array}$ & 2 & 6 & 6 & 0 & 62 & 8 & 84 & $25.0 \%$ \\
\hline $\begin{array}{l}\text { District of New } \\
\text { Mexico }\end{array}$ & 2 & 2 & 3 & 0 & 12 & 0 & 19 & $50.0 \%$ \\
\hline $\begin{array}{l}\text { Northern } \\
\text { District of } \\
\text { Oklahoma }\end{array}$ & 1 & 1 & 2 & 0 & 33 & 2 & 39 & $50.0 \%$ \\
\hline $\begin{array}{l}\text { Eastern District } \\
\text { of Oklahoma }\end{array}$ & 0 & 1 & 1 & 0 & 0 & 0 & 2 & $0.0 \%$ \\
\hline $\begin{array}{l}\text { Western } \\
\text { District of } \\
\text { Oklahoma }\end{array}$ & 3 & 12 & 3 & 0 & 34 & 5 & 57 & $20.0 \%$ \\
\hline District of Utah & 15 & 39 & 34 & 2 & 247 & 20 & 357 & $27.8 \%$ \\
\hline $\begin{array}{l}\text { District of } \\
\text { Wyoming }\end{array}$ & 0 & 1 & 0 & 0 & 10 & 1 & 12 & $0.0 \%$ \\
\hline Subtotal & 32 & 89 & 77 & 2 & 683 & 53 & 936 & $26.4 \%$ \\
\hline $\begin{array}{l}\text { Eleventh } \\
\text { Circuit }\end{array}$ & 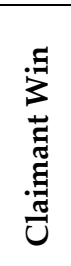 & 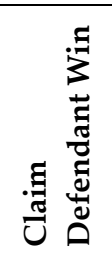 & 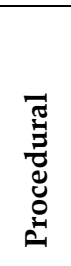 & 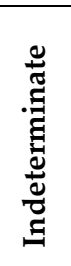 & 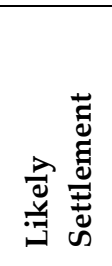 & 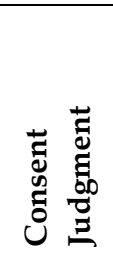 & 岕 & 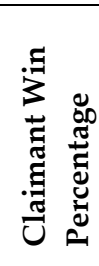 \\
\hline $\begin{array}{l}\text { Northern } \\
\text { District of } \\
\text { Alabama }\end{array}$ & 2 & 2 & 6 & 0 & 27 & 9 & 46 & $50.0 \%$ \\
\hline $\begin{array}{l}\text { Middle District } \\
\text { of Alabama }\end{array}$ & 0 & 0 & 0 & 0 & 6 & 0 & 6 & N/A \\
\hline $\begin{array}{l}\text { Southern } \\
\text { District of } \\
\text { Alabama }\end{array}$ & 1 & 2 & 1 & 1 & 6 & 0 & 11 & $33.3 \%$ \\
\hline
\end{tabular}




\begin{tabular}{|c|c|c|c|c|c|c|c|c|}
\hline $\begin{array}{l}\text { Northern } \\
\text { District of } \\
\text { Florida }\end{array}$ & 1 & 1 & 3 & 0 & 19 & 3 & 27 & $50.0 \%$ \\
\hline $\begin{array}{l}\text { Middle District } \\
\text { of Florida }\end{array}$ & 25 & 29 & 49 & 2 & 277 & 47 & 429 & $46.3 \%$ \\
\hline $\begin{array}{l}\text { Southern } \\
\text { District of } \\
\text { Florida }\end{array}$ & 25 & 65 & 71 & 1 & 282 & 34 & 478 & $27.8 \%$ \\
\hline $\begin{array}{l}\text { Northern } \\
\text { District of } \\
\text { Georgia }\end{array}$ & 7 & 54 & 69 & 1 & 265 & 61 & 457 & $11.5 \%$ \\
\hline $\begin{array}{l}\text { Middle District } \\
\text { of Georgia }\end{array}$ & 2 & 0 & 2 & 0 & 14 & 1 & 19 & $100.0 \%$ \\
\hline $\begin{array}{l}\text { Southern } \\
\text { District of } \\
\text { Georgia }\end{array}$ & 1 & 1 & 1 & 0 & 7 & 1 & 11 & $50.0 \%$ \\
\hline Subtotal & 64 & 154 & 202 & 5 & 903 & 156 & 1484 & $29.4 \%$ \\
\hline $\begin{array}{l}\text { District of } \\
\text { Columbia } \\
\text { Circuit }\end{array}$ & 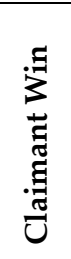 & 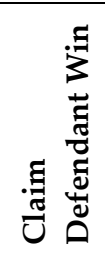 & 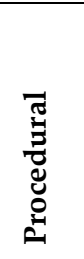 & 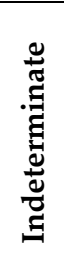 & 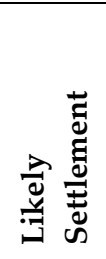 & 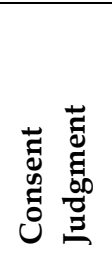 & 岕 & 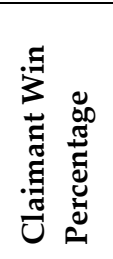 \\
\hline $\begin{array}{l}\text { District of } \\
\text { Columbia }\end{array}$ & 9 & 25 & 19 & 0 & 59 & 3 & 115 & $26.5 \%$ \\
\hline Subtotal & 9 & 25 & 19 & 0 & 59 & 3 & 115 & $26.5 \%$ \\
\hline \multirow[t]{2}{*}{$\begin{array}{l}\text { TOTAL } \\
\text { OUTCOMES }\end{array}$} & 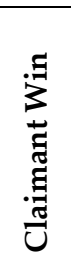 & 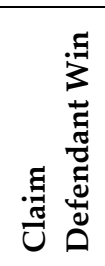 & 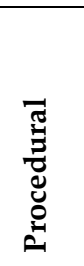 & 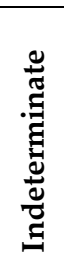 & 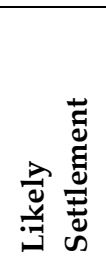 & 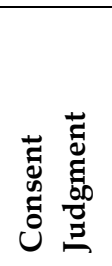 & 岕 & 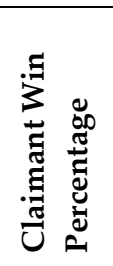 \\
\hline & 989 & 2054 & 2223 & 37 & 14542 & 1822 & 21667 & $32.5 \%$ \\
\hline
\end{tabular}

